\title{
The construction of Brunelleschi's dome in Florence in the fifteenth century: between accountability and technologies of government
}

\author{
Giacomo Manetti, Marco Bellucci \& Luca Bagnoli
}

To cite this article: Giacomo Manetti, Marco Bellucci \& Luca Bagnoli (2019): The construction of Brunelleschi's dome in Florence in the fifteenth century: between accountability and technologies of government, Accounting History Review, DOI: 10.1080/21552851.2019.1686036

To link to this article: https://doi.org/10.1080/21552851.2019.1686036

曲 Published online: 04 Nov 2019.

Submit your article to this journal $₫$

Q View related articles $\asymp$

View Crossmark data $\complement$ 


\title{
The construction of Brunelleschi's dome in Florence in the fifteenth century: between accountability and technologies of government
}

\author{
Giacomo Manetti, Marco Bellucci (i) and Luca Bagnoli \\ Department of Economics and Management, University of Florence, Florence, Italy
}

\begin{abstract}
Accounting practices played a fundamental role in the construction of Brunelleschi's dome of Santa Maria del Fiore in Florence during the fifteenth century. This study examines the accountability practices and government technologies adopted by the Opera del Duomo, the organisation entrusted to build and maintain the Cathedral of Florence, between 1420 and 1436, when the dome was constructed. This research draws on the theories of Foucault and Dean regarding technologies of government within quasipublic administrations to explain historical evidence for the accountability practices supporting Brunelleschi's dome construction. Through the collected evidence, we identify the application of 'technologies of government' hundreds of years before Foucault's arguments about governmentality. We also describe a system of accountability, especially downward accountability, inspired by religious values that pays attention to users, the local community and other affected constituents as a result of the Opera's special status as a 'quasi-public' (but formally private) administration. Our findings touch on the willingness to account for and report public funding, the presence of checks and balances inside the governance framework, the active engagement of citizens and local partners to achieve consensus, and notions of social responsibility toward the workers who helped to build the dome.
\end{abstract}

\section{ARTICLE HISTORY}

Received 8 October 2018

Accepted 24 October 2019

\section{KEYWORDS}

Accountability; Florence;

Brunelleschi; bureaucracy; technologies of government; dome

\section{Introduction}

This study examines the accountability practices and government technologies that were adopted by the Opera of Santa Maria del Fiore when the Cathedral of Florence was being built, giving special attention to the years in which Filippo Brunelleschi's (1420-1436) legendary dome was constructed. Although many historical studies have focused on the architectural and artistic accomplishments of the first octagonal dome built without a temporary wooden supporting frame - which is surely one of the most impressive projects of the early Renaissance - less attention has been devoted to the various systems of accounting and accountability that were implemented by the Opera, thus contributing to the success of the enterprise. 
The present manuscript is the result of archival research, including original statutes and accounting books that address the administration of both the Opera of Santa Maria del Fiore and the Wool Guild, the organisation that acted as the link between the Republic of Florence and the Opera itself. We analyse these archival materials and interpret our results using a theoretical framework based on the theories of Foucault and Dean, while also stressing the role of accountability and technologies of government among quasipublic administrations. This approach enables us to produce findings that touch on the concepts of accountability, bureaucracy, and governmentality.

The main aim of this study is to contribute to the accounting history literature by answering an exploratory research question on whether and how accountability systems, conceived as signs of government technologies and bureaucracy, were specifically adopted by a quasi-public institution - the Opera del Duomo in Florence - during the construction of the Florentine Cathedral dome (1420-1436). We believe that this research question is original since the study concerns an early Renaissance application of the idea of 'technologies of government' (elaborated by Foucault for modern democracies) in one of the first attempts of Italian Republics (a semi-oligarchic regime), which can contribute to the understanding of possible prodromes and the origins of Foucault's 'technologies of government' (Sargiacomo 2009, 237). A further element of interest in this study is related to the application of these governmental technologies not by a democratic state but by a 'quasi- public' institution. The historical era in which we apply the Foucauldian concept of 'technologies of government' and the context of an Italian semi-oligarchic regime are original, and their study can contribute to the advancement of knowledge related to the functioning of modern democracies, as proposed by Foucault. Furthermore, unlike funding for other great Italian Gothic Cathedrals, such as Orvieto and Milan, where the contributions of private individuals were decisive, almost all the funds made available in Florence can qualify as 'publicly attributed', with a negligible role of almsgiving or direct contributions of the Wool Guild (Haines 2002). This aspect, together with the search for consensus of every local actor involved in the project, make the construction of the Cathedral in Florence and its dome a peculiar case from the perspective of accountability.

In light of the foregoing elements, this research can provide a new and original view of the technologies of government - beyond what we know today - applied to a great and unique architectural public project never attempted before the fifteenth century. The technology that we analyse consists of a complex, rare, and effective 'medieval accountability system' that includes the presence of checks and balances and of consensus-building mechanisms.

This study contributes to the accounting literature in three main ways. First, the research illustrates how the construction of the dome represented a technology of government, as it gave job opportunities and a primordial form of family assistance to all the project workers. It also provided its citizens with an ideal, religious and imaginative goal - the completion of the Cathedral, yielding a spectacular aesthetic and architectural result. Moreover, after decades of work interruption to complete the Cathedral, the dome construction contributed to the strengthening of the ideas of the Opera in the eyes of the citizens of Florence and to the lordship that represented the actual government of the Florentine Republic at that time. Second, since this enterprise was primarily financed by public funds, it is possible to find a particular technology of government in the accountability, governance, and bureaucratisation practices implemented by the 
Opera to strengthen its relationship with the Republic and its citizens, especially in terms of legitimisation. In light of the above, this study adds an early Renaissance analysis, applied to the Italian context, to the literature. The Republic of Florence, in fact, represents one of the first attempts at 'democratic' (in terms of quasi-oligarchic) government. In the context of the Florentine Republic, technologies of government were widely used for consensus building, thus matching the beginning of some prodromes of governmentality (Sargiacomo 2009, 237). The use of public funds in the context of an early-Renaissance 'democratic' government fostered the emergence of rational, bureaucratic practices of technology of government as signs and prodromes of 'governmentality' (Foucault 1984a, 1984b, 2010), understood as transforming society into an increasingly bureaucratic entity (Baker and Rennie 2017). Although Foucault emphasised the period after the Industrial Revolution, we believe that prodromes of this system, especially in terms of accountability systems and bureaucracy, are traceable within the Opera during the construction of Brunelleschi's dome. With prodromes we intend the early, primitive, and partial empirical traces of a concept developed for a later historical period. For example, the concept of accountability is, at least at first glance, primarily recognisable as a modern concept. Yet it is interesting to understand how and why elements of what we call an accountability system were in fact adopted during the early Renaissance in the case of the Opera. Third, the particular historical period and context of this study and its focus on an original institution that operated as a quasi-public organisation strictly linked with the Republic of Florence constitutes a new strand of research for accounting historians, especially if one considers the attempt to apply the 'technologies of government' idea centuries before the period studied by Foucault.

The remainder of this study is organised as follows: the next two sections discuss the socio-economic context of Florence during the early Renaissance - especially 14201436, when Brunelleschi's dome was constructed. After a detailed presentation of our methodology and historical sources, the section 'Accountability and governmentality in the shadow of the dome' discusses our theoretical framework and how the concepts of accountability, bureaucracy, and governmentality informed how we have interpreted our primary and secondary sources. The subsequent subsections discuss our findings on the willingness to account for and report public funding, the presence of checks and balances inside the governance framework, the active management of citizens and local partners and their consensus, and social responsibility toward workers. The final section provides concluding remarks on accountability, bureaucracy, and governmentality during the construction of Brunelleschi's dome.

\section{Context of the early Florentine Renaissance}

In the fifteenth century, Florence was among the largest, richest, and most economically developed cities in Europe (Najemy 2008). Its first decades are occasionally designated the early Renaissance in the sense that they anticipated the flourishing of the Italian and then European historical period that represents the cultural bridge between the Middle Ages and the early modern era. It was based on a new version of humanism derived from the rediscovery of classical Greek philosophy. At the beginning of the fifteenth century, Italy was divided into many city-states that were either nobility regimes or Republics (Hyett 1903). Florence, like many other Italian city-states, was among those states 
controlled by a commercial élite as a Republic (Haakonssen 1995). Of course, the concept of a Republic was quite different from the present homonym. Florence did not have a government where everyone voted for representatives who would represent their interests but rather an oligarchic regime based on a constitution that limited the power of the nobility and ensured that no one person or group could have complete political control (Najemy 2008). Despite the title of 'Republic of Florence', in fact, only a small percentage of the population had the right to vote, and political power was concentrated in the hands of a few wealthy families active in trading and banking activities and of the powerful Guilds, including the Wool Guild.

The Cathedral project is linked to the extraordinary wealth accumulated in Florence during the last phase of the Middle Ages given the growing middle and upper classes of merchants and bankers who had relationships with many Italian and European states (Peterson and Bornstein 2008). With the accumulation of wealth, the patrons of Florence wanted to invite the greatest artists and architects to build an ideal city. The desire was to make Florence a great and human-scale city, not with an exclusive focus on the present but with the potential to last for centuries (Goldthwaite 1968). Either the citizens of Florence, especially the main exponents of the Guilds, saw their city as a state-of-the-art place where the freedom of individuals was guaranteed and where many citizens had the right to participate in its government (Goldthwaite 1980). The common sense of belonging of Florentine citizens was based on the principles of respect of individuals' opinions, since individualism was a critical part of the humanism that thrived in Florence in the fifteenth century. Nevertheless, life conditions were not ideal for all Florentine citizens; there were great disparities in wealth, and many people suffered from food shortages and illnesses, particularly recurring plague epidemics (Cipolla 1976; Carmichael 1986; Henderson 1994).

The Republic of Florence was ruled by a council (the 'Signoria') of nine members (the 'Priori') who were chosen from the ranks of the city Guilds: six of them from the major Guilds and two from the minor Guilds. The ninth became the Gonfaloniere di Giustizia, a temporary standard-bearer of justice of the Republic of Florence, also in charge of the maintenance of public order and internal security forces (Najemy 2008). The Republic was characterised by very frequent coups and countercoups as a result of the struggle among the diverse factions.

The Albizi family, rich wool traders and leaders of the faction called 'guelfi neri' (close to the interests of the Pope), had held high office in the Republic since the end of the thirteenth century (98 Priori and 13 Gonfalonieri di Giustizia). At the end of the fourteenth century (1393), Maso Albizi (1343-1417) was appointed 'Gonfaloniere di Giustizia'. After the death of Maso, his son Rinaldo retained leadership of the oligarchic regime of Florence (Strathern 2007). Without the leadership of his father, Rinaldo fared worse in political fighting and was exiled to Ancona in 1434. The Medici family, returning from exile in Venice, gained control of the city in 1434 upon Cosimo de' Medici's countercoup against the faction that had sent him into exile in the previous year (Strathern 2007).

The Medici were rich and famous bankers and patrons who were well regarded by the papacy, thus contributing to their ascendancy in the city-state of Florence. The family, through the achievement of the 'Signoria' lordship (a form of governing authority in force in many Italian city-states during the medieval and Renaissance periods), already played an active role in Florence's government in the fourteenth century (Rubinstein 1971; Kent 1978, 2000). The Medici, who had begun their political involvement early in 
the century, are said to have used the crisis of the war with Lucca and Milan (1429-1433) to move into important offices. They and their partisans practically directed the war effort, and Medici money was crucial in financing the Republic (Padgett and Ansell 1993). Cosimo was also noted for his patronage of culture and the arts during the Renaissance and liberally spent part of the family fortune to enrich the civic life of Florence (Kent 2000). Additionally, his patronage of the arts both recognised and proclaimed the humanistic responsibility of the civic duty that came with wealth (Jurdjevic 1999). He was a patron and confidante of many artists and designers, including Filippo Lippi, Donatello, and the architect Brunelleschi, who designed and supervised the work of the dome.

\section{Years of the dome construction (1420-1436)}

Against this background, Brunelleschi's dome was constructed between 1420 and 1436 . However, the project of the Santa Maria del Fiore Cathedral dates back to 1296, when the Opera was informally founded with the main aim of realising this initiative.

In the first three decades of the project, public funding was sporadic and linked to individual assignments periodically decided by the local government, with the recurring motivation that the project, in addition to honouring God and the Virgin Mary, would bring glory and decorum to the city of Florence. However, once the enthusiasm of the early years had passed, the funding for the realisation of the project became discontinuous with consequent blocking of the works for periods of several years. Only in 1331 was it decided to remedy the problem of the discontinuity of the funds, changing the administrative and financial systems. In the same year the Opera of Santa Maria del Fiore was formally constituted by the powerful Wool Guild and the municipality of Florence decided to give to the Opera permanent public subsidies. After a couple of years, as further explained later in the text, the Wool Guild was allowed to appoint the Officials (Operai) of the Opera who had the task of converting public funding into the building of the Cathedral. Shortly thereafter, their task was to entrust and collect the funds owed by the municipality or by individual citizens (Haines and Riccetti 1991; Haines 2002).

The Wool Guild was one of the most powerful in the city and notably the one that counted the greatest number of workers, approximately one third of the Florentine population. The corporation prospered until the beginning of the fifteenth century when, due to both a decline in trade and changes of fashion tastes, it had to cede supremacy to the Silk Guild. The Wool Guild exercised its patronage on the Opera del Duomo, entrusted directly by the Signoria in 1331. Although it has been reformed frequently over the centuries, the Opera has always remained responsible for the building, administration, conservation and valorisation of the Cathedral and even today has responsibility for the archive that documents all the historical phases of its activities. As highlighted by Haines $(2012 \mathrm{a}, 47)$,

standing proud over Florence for almost six centuries, Brunelleschi's dome holds all the mythattracting ingredients: mammoth size, striking form, assertive colour, [and] axial position in the city that spawned the Renaissance of the visual arts.

The dome, in fact, was realised with a double-shelled octagonal cloister vault that was erected according to Brunelleschi's architectural innovation, without resorting to the support of soaring Gothic vaults that characterised many churches built during the fourteenth and fifteenth centuries (including the crossing arms of Florence's Cathedral itself). 
In other words, the dome is an example of innovative architectural and technical project planning and building (Guasti 1857; Hyman 1974; Saalman 1980); for centuries, it has been a source of inspiration for architects and artists. According to Kent (2000, 122-128), the vision of the cupola was as an icon of popular culture and locus of civic power. Figure 1 depicts a beautiful section of Brunelleschi's dome authored by Sgrilli (1733). Unlike

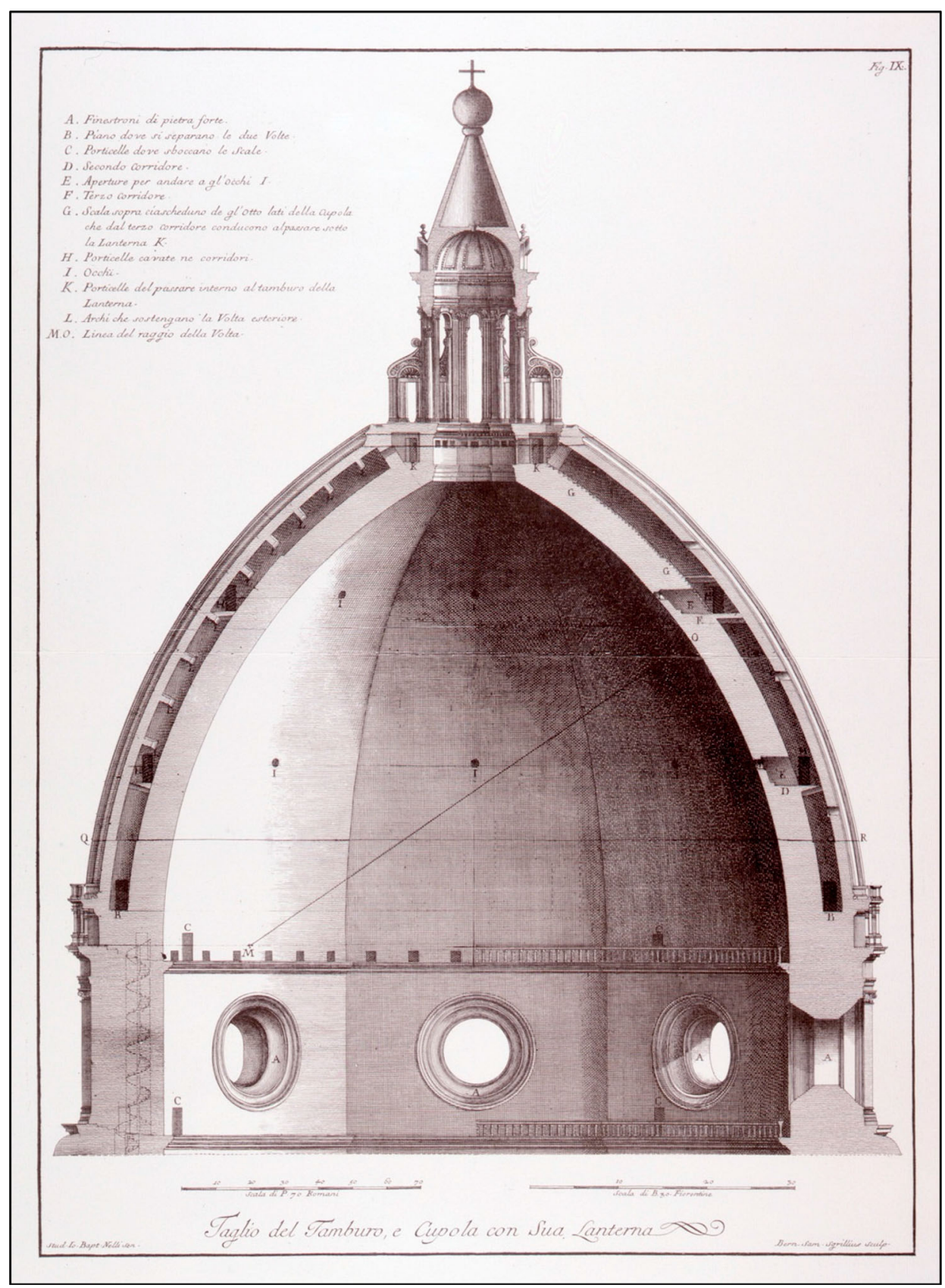

Figure 1. Transverse section of Brunelleschi's dome.

Source: Sgrilli (1733). 
other projects for medieval cathedrals in which the unfinished cathedral signified the impossibility of a complete alignment among the civic, financial, architectural and religious representations of the artefact as conceived by its planners (see, for instance, the role of 'absences' and incompleteness in the building of the Siena Cathedral in Giovannoni and Quattrone [2018]) and in a context in which it was not uncommon for Gothic cathedrals to be left unfinished (Tagliaventi 2009), the project of the dome in Florence succeeded in meeting the consensus of almost all of the actors involved in its construction: Church, Republic of Florence, Wool Guild, and the local community.

When the Cathedral was designed in the previous century, no notion existed of how to realise such a project, given that no dome of that size had been built since antiquity. Given that buttresses were forbidden by the people responsible for building the Cathedral (the so-called Operai), and rafters long and strong enough for scaffolding were impossible to build at that time, the completion of the dome seemed to be a utopian dream, especially considering the potential weight of the entire structure (King 2000).

In the attempt to find a solution, on 18 August 1418, the Wool Guild announced an architectural design competition for erecting the dome (Haines 1996). Although the public competition had no official winners, the task was entrusted to Filippo Brunelleschi (Krautheimer 1982) and Lorenzo Ghiberti, who initially received a salary equal to that of Brunelleschi but was later excluded from the project. Brunelleschi and, partially, Ghiberti directed its construction from 1420 to 1436 (Haines 2012a), the year in which the entire Cathedral was consecrated by Pope Eugene IV.

\section{Sources and methodology}

Archival research is an important part of our project. Thus, we have adopted a qualitative approach that is based on the analysis of primary documents and other artefacts that can be used to trace the history of a specific organisation (Bryman and Bell 2015). Document analysis requires that data are examined and interpreted to elicit meaning, gain understanding, and develop empirical knowledge (Rapley 2007; Corbin and Strauss 2008; Bowen 2009).

According to Munslow (2007), the rational, independent, and impartial investigation of historical documents represents one of the most valuable aspects of a historian's work.

The findings presented in our study are based on the examination of the primary and secondary sources outlined in Tables A1 and A2 of the Appendix. These sources relate to the 'foundations' of the dome - the governing, accounting, and reporting practices that were implemented to sustain the construction of such an innovative architectural masterpiece. The sources mentioned, particularly the revenue and expense registers, document the procurement of materials, the management of the workforce, the structure of the institution itself and its efforts to collect the financial rights that were due to it. They also highlight its presence in the context of liturgy, and its relations with the city and the great civic enterprise of the Cathedral. ${ }^{1}$

Considering our theoretical framework, the primary sources in Table A1 can represent technologies of government. More specifically, registers and statutes were conceived as 'practical rationalities' (Dean 1996), which are means for the creation of authority and mechanisms for co-ordination or division in time and space (Carmona, Ezzamel, and Gutiérrez 2002). Moreover, the statute of the Wool Guild provides invaluable information 
on the role played by politics and ethics in shaping the accounting mechanisms designed by the Opera during the years of the dome construction. Primary sources are currently preserved in the Opera archives, apart from the Wool Guild statute, which is conserved in the state archives ('Archivio di Stato') of Florence. These sources, together with the secondary sources referenced in Table A2, allow us to examine the historical, institutional, and organisational contexts surrounding the Opera while it managed the construction of the Cathedral and, in particular, of the dome.

Secondary sources represent a valuable resource for our study. We have relied extensively on relevant manuscripts authored by prominent scholars that enable us to understand how the Cathedral project fit as a public work in the early Renaissance context in Florence from a political, institutional, and financial perspective. Through the lens of the documents referenced in Table A2, we have reconstructed the role of accountability and governing practices adopted by the Opera and its institutional history during the years of the dome construction, as illustrated in the next sections.

The process of selecting and interpreting the archival documents was assisted by two experts from the archive of the Opera. These archivists assisted us in our reading of the documents - which were written in Latin or in the specific vernacular used in Florence in the late Middle Ages - and participated in three unstructured interviews that provided us with many insights into the history of the Opera, providing further validation of our overall reconstruction of the historical background of this research.

\section{Accountability and governmentality in the shadow of the dome}

Through the study of the extensive set of primary and secondary sources highlighted in the previous section, it is possible to investigate the role of accountability, bureaucracy, and technologies of government in the Opera, with reference to the period of dome construction (1420-1436).

The concept of 'governmentality', which was originally elaborated by Barthes (1957) and subsequently reworked by Foucault at the beginning of the 1980s (Foucault 1984a, 1984b, 2010), can be used to explain how rational ideas worm their way into the larger culture, thus transforming society into an increasingly bureaucratic entity (Sargiacomo et al. 2016; Baker and Rennie 2017). Although Foucault emphasised the period after the Industrial Revolution, we believe that his research represents a valuable lens through which to interpret the accounting system and bureaucracy that was put in place by the Opera of Santa Maria del Fiore during the construction of Brunelleschi's dome. More specifically, a rationalised government often includes bureaucracy, secularisation and individualisation (Smart 1995). In this light, the implementation of bureaucracy in government and governance is a type of rationalisation aimed at the achievement of a certain objective or a specific goal. Weber (1922) cites several preconditions for the proliferation of bureaucracy: the increasing complexity of the administrative tasks being carried out, the presence of a monetary economy that requires a more efficient administrative system, and population growth. All these conditions were present during the fifteenth century when the Republic of Florence and the Church - through the Opera of Santa Maria del Fiore carried out a project to construct Brunelleschi's dome (Grote 2009).

Dean identifies different kinds of punishment, care, assistance, and education that are included in the umbrella expression 'technologies of government' (Dean 1996, 52). 
According to Dean, 'practical rationalities' and 'specialist knowledge' are the typical technologies of government. 'Practical rationalities' are represented by programmes, policies and plans that reflect technology, defining its action in relation to defined aims, whereas 'specialist knowledge' involves a wide gathering of people, theories, projects, and techniques that are the central components of government (Rose and Miller 1992, 177-178).

Miller and Rose $(1990,8)$ provide more insights into the concept of 'technologies of government' as a mechanism through which authorities of various sorts have sought to shape, normalise and instrumentalise the conduct, thought, decisions, and aspirations of citizens to achieve the objectives they consider desirable (Miller and Rose 1990, 8). Specifically, it is through technologies such as techniques of notation, computation and calculation, procedures of examination and assessment, surveys, and tables that authorities seek to instantiate government (Rose and Miller 1992, 183; Lemke 2001, 191). There is a constitutive interrelationship between quantification and governmentality (Rose 1991); techniques of bookkeeping, accounting, assessment, and reporting represent typical tools used by central and local authorities for refining governmentality via the technologies of government (Rose and Miller 1992, 177-178). With reference to the Opera, rationalising forms of quantitative knowledge, as significant forms of technologies of government', can be found. Given its quasi-public administration nature, funded by public resources and influenced by both political and religious powers, the Opera found itself in need of guaranteeing greater 'downward accountability' (Kearns 1996; Ebrahim 2005) to users, the local community, and other affected constituents. Moreover, the literature on the third and quasi-public administration suggests that an organisation's national institutional context, which includes legal, regulatory, and professional structures, influences its propensity to adopt pervasive tools of accountability (Holloway, Francis, and Hinton 1999; Guarini, Magli, and Nobolo 2018).

Among the possible forms of accountability, Roberts $(1991,1996)$ divides the concept into individualising and socialising forms. Roberts (1991) associates the individualising form of accountability with Foucault's notions of disciplinary power and argues that this association is maintained by the formal structures of organisations, of which accounting practices represent an important example. He also suggests (Roberts 1996) that the individualising form of accountability can be destructive in constructing 'the self' as an atomised individual and obscuring the interdependent nature of organisational life (Jacobs and Walker 2004, 362). This individualising aspect of accountability, linked to formal organisational structures, represents the principal focus in the accounting literature. The socialising aspect of accountability (Gambling, Jones, and Karim 1993; Ryan, Scapens, and Theobald 2002), by contrast, has remained relatively unexplored because it is associated with communicative actions and interactions with social partners from a downward perspective. Our case can shed light on some significant early Renaissance prodromes of socialising aspects of accountability that were utilised as rationalising forms of quantitative knowledge from a governmentality perspective.

Considering the literature and theories described above and the sources and methodology depicted in the previous section, we can understand what type of accountability systems, conceived as signs of government technologies and bureaucracy, were adopted by the Opera during the cupola construction. In the next subsections, we focus on the willingness to account for and report public funding, the presence of checks and 
balances inside the governance framework, the active management and the consensus of citizens and local partners, and the social responsibility toward workers.

\section{A collectively funded civic enterprise}

The construction of the Cathedral and its dome was financed primarily by public funds (Haines 2002; Fabbri 2003), thus it had to symbolise transparency, trustfulness, and managerial excellence. As highlighted earlier, unlike funding for other great Italian Gothic cathedrals, almost all of the funds made available in Florence can qualify as 'publicly attributed', with a negligible role for almsgiving or direct contributions from the Wool Guild (Haines 2002). On average, the camarlingo of the Opera received 1.5 per cent of the city's budget in the period between 1331 and 1433 (Haines 2002; Fabbri 2003), in addition to a few other una tantum payments. The main sources of income were a percentage of the four main taxes of the municipality: city gates (customs), contracts, salt, and wine (Giorgi 1997; Haines 2002). The trend of the consistency of the Opera's monetary reserves followed the trend of the 'fat' or 'lean' times of the Republic. Peace and good crops favoured more-generous incomes from the gabelle (indirect taxes), with an increase in the relative percentages dedicated to the Cathedral. In contrast, famine, plague, and wars reduced the tax base on the one hand; on the other hand, those situations led the government to reduce or suspend funds urgently required elsewhere (Giorgi 1997; Haines 2002). ${ }^{2}$

The delegation of the administration of a large enterprise of civic interest, whether or not ecclesiastical, to the artisan Guilds was an exquisitely Florentine practice. The municipality relied on the sobriety, wisdom, correctness and organisational capacity of the entrepreneurial bourgeoisie of the city to guarantee, with respect to the community, the management of works considered of public importance (Haines 2002). Analysing this scenario within the lens of our theoretical framework invites us to interpret the Wool Guild as the necessary link between a set of technologies of government and other kinds of technologies, such as production and communication, carried out by the Opera. This kind of link between the municipality and the Opera was a system with the ability to influence objects, people, and capabilities (Dean 1996) and was responsible - and accountable - for the outcomes of its activities. What the Municipality of Florence was looking for and needed were managerial skills to manage public money in the most efficient and transparent way possible and to ensure that construction could be completed. The search for technical competencies in the private sector would be repeated years later, in the period from 1490 to 1530, with the partnership between the Republic of Florence and the Misericordia for managing the plague (Manetti, Bellucci, and Bagnoli 2017).

The Opera management had to account for how funds were used and to report not only to the Wool Guild but also, at least in the first phase, to the municipality (Guasti 1887). The seriousness with which the Wool Guild felt responsible for the proper functioning of the Opera is evident in numerous acts. Regular inspections by the Guild consuls at the Opera headquarters, twice for each consulate according to the 1428 statute, are regularly recorded in the accounting books of the Opera, together with the expenses for small refreshments offered on occasion (Haines and Riccetti 1991). Figure 2 shows the accounting entry for the petty expenses of one of these visits in 1422: 


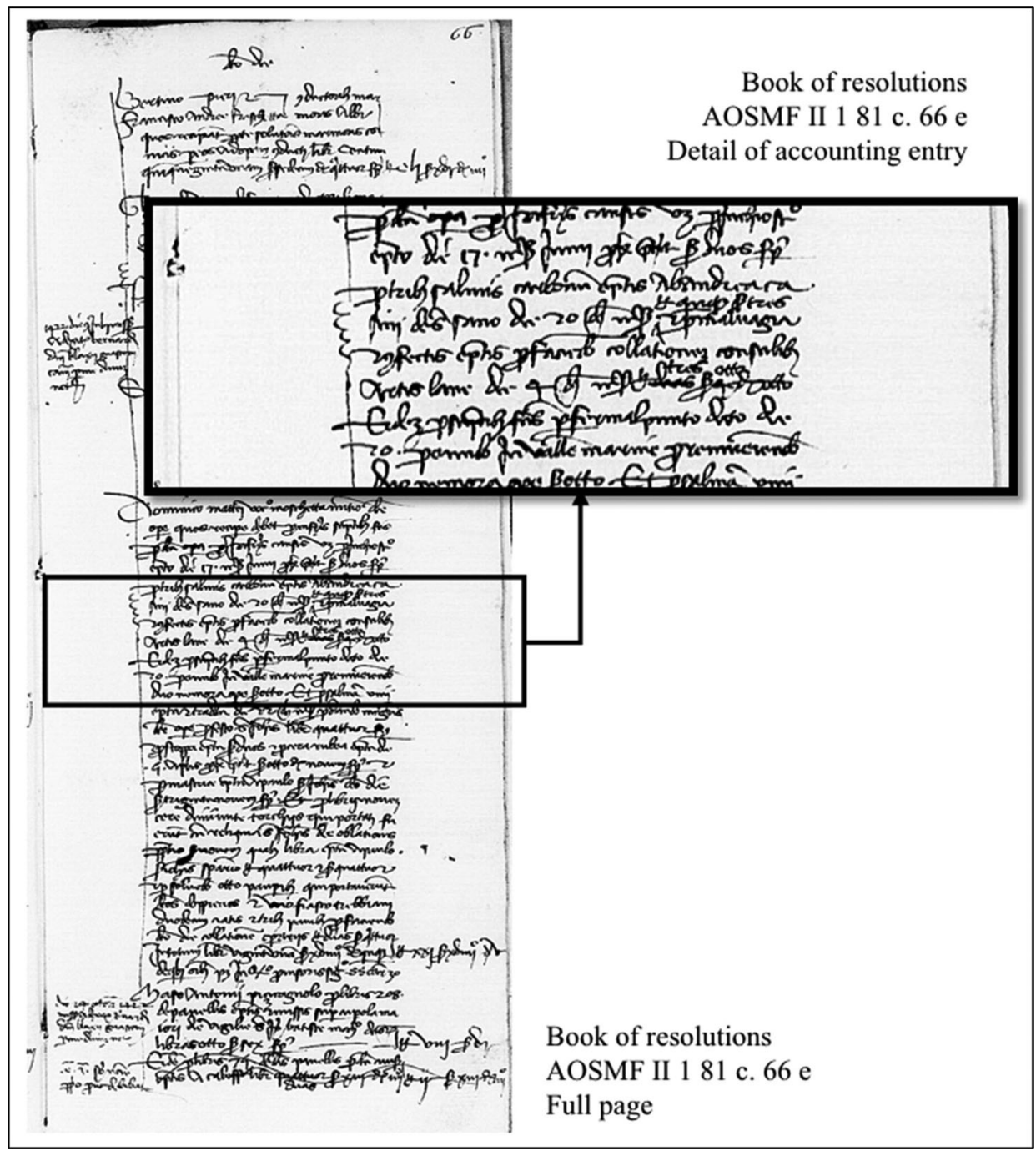

Figure 2. Accounting entry concerning petty expenses for a breakfast offered to the Wool Guild consuls during their visit at the Opera headquarters in 1422.

Source: Book of resolutions - AOSMF II 181 c. 66 e.

and for the malvasia wine and the confits purchased to prepare breakfast for the consuls of the Wool Guild on the 4th of that month [must receive] 3 lire 8 soldi and 8 denari ${ }^{3}$ (Book of resolutions, AOSMF II 181 c. 66 e).

The approval of the consuls was also necessary for permission for burial in the Cathedral. This rule was based on the principle that the new Cathedral, desired and financed by the entire city, should not become the scene of display for private clients with tombstones or chapels - which inevitably accompanied the noble tombs (Haines and Riccetti 1991). In fact, a deliberate policy of closure existed against every element of private presence, reserving burial in only extraordinary cases of individuals considered meritorious to the community (Fabbri 2003). 
Another sign of the collective participation in the financing of the Cathedral is the presence of the 'tax on testaments'. One of the oldest rights due to the Opera, in fact, was a mandatory legacy of a variable sum in every will carried out in the territory of the city (Fabbri 2003). This right was granted for the first time by a 1296 municipal provision coinciding with the foundation of the new Cathedral (Guasti 1887). Given the complex nature of the arrangement, however, it was difficult to collect the proceeds. In 1359, the Opera was granted full powers to collect its rights in relation to testamentary bequests (Haines 2002). Consequently, we find at the Opera, in addition to the notary general, a 'notary of the testaments', paid in variable forms with a percentage of up to 20 per cent of the total legacy, specifically in charge of finding the debtors responsible for this cause.

Figure 3 shows the accounting entry for a payment on 23 January 1420 to the debt collector of the indirect taxes on contracts singling out testaments and testators favouring the Opera:

to Filippo di Giovanni, the tax collector of the gabelle of contracts for having deduced numerous testaments from the books of that gabelle, that is to say names of testators, and having transcribed them in a notebook'. ${ }^{4}$ (Book of resolutions, AOSMF II.1.77, c. 56c) The same entry is double-checked using the book of allocations (AOSMF II.4.8, c.65v).

In light of all the processes described, the Florentines were always clearly aware of being the true owners of the Opera del Duomo, precisely because they had provided financial support through various forms of payment of a virtual, composite 'tax on Santa Maria del Fiore' (Fabbri 2003). Consequently, the capacities in terms of accountability and good governance of the Opera appear to be crucial in the context of the Florentine municipality and the relation between its governance and public opinion.

\section{Checks and balances for good governance and accounting}

As mentioned previously, the Florentine situation was completely anomalous in the context of Italian religious institutions devoted to new cathedral construction. In fact, the main aspect that distinguishes the Opera of the Cathedral of Santa Maria del Fiore from those of other Italian cities is that it had interposed between itself and the city government one of the great mercantile corporations of the city, the Wool Guild (Haines and Riccetti 1991). The latter is a Florentine custom to entrust the management of factories supported by public funds to the merchant corporations. The practice was an expression of the trust placed in the administrative capacities of great entrepreneurs who led the major Guilds dedicated to industry and commerce and who fought for the honour and charges of such delegations (Haines and Riccetti 1991).

The political control of an institution so important for the Florentine Republic - the one entrusted with building the new symbol of the city's greatness - fell into the hands of a delimited sector, albeit a crucial one, of the Florentine patriciate (Fabbri 2001). Additionally, to respond to the new requirements derived from the management of this initiative, the Wool Guild drew up a new statute in 1333, promptly defining a special structure consisting of four Operai (Officers) and a Camarlingo (Treasurer) elected from representatives of the Wool Guild and a notary (elected from candidates outside the Guild). The statute of 1333 laid down a normative basis that, despite several changes in the coming decades, remained broadly in force for more than a century (Haines and Riccetti 1991; Giorgi 1997). The treasurer had to collect and record all the incomes due to the Opera and could pay the same amounts only after the allocation of the Operai registered by the 


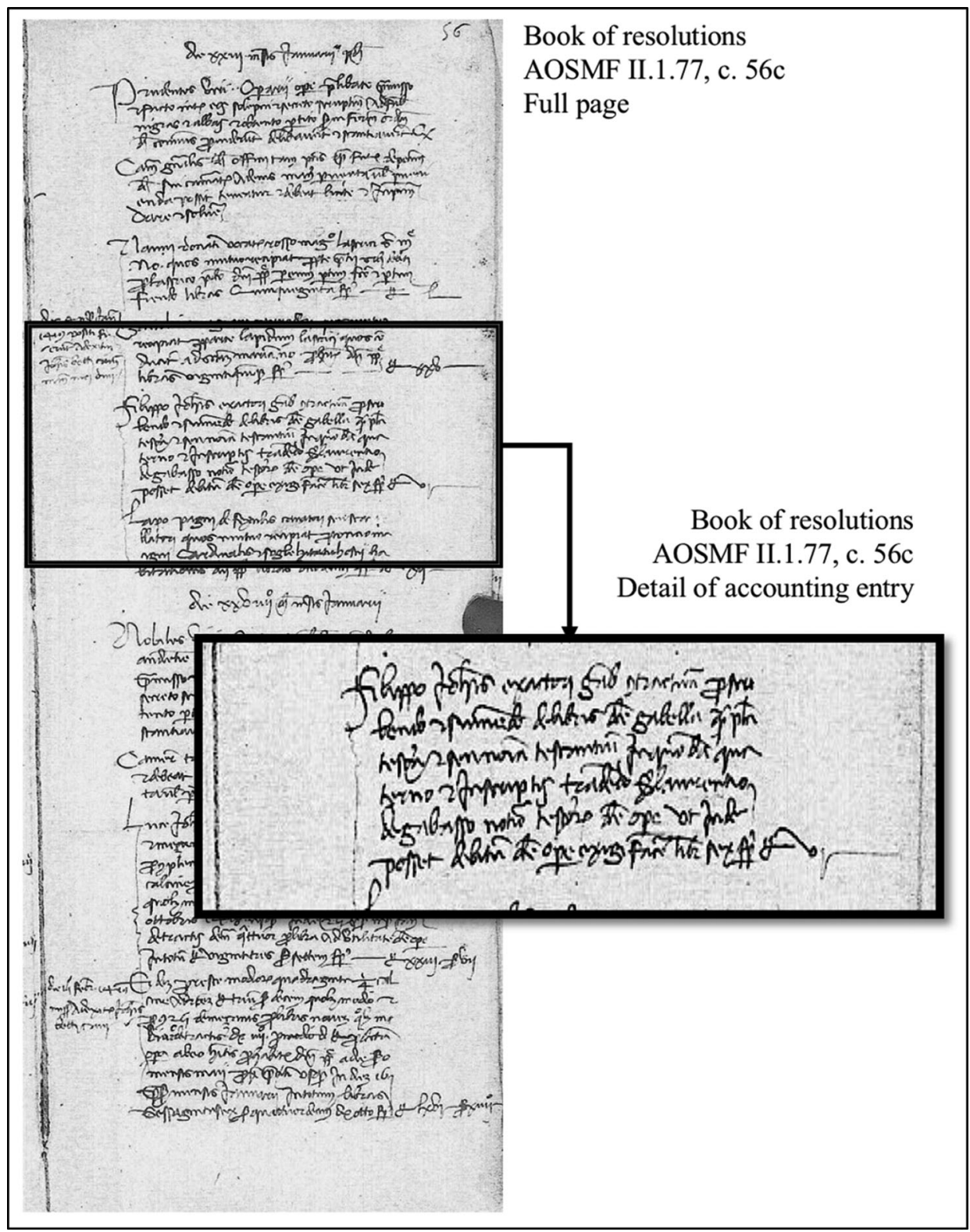

Figure 3. Accounting entry concerning the payment to the notary of the testaments for the gabella on contracts singling out testaments and testators favouring the Opera.

Source: Book of resolutions - AOSMF II.1.77, c. 56c.

notary (Saalman 1980). The treasurer was essentially called to ensure proper management of the Opera reserves. In turn, the Camarlingo was controlled by the Provveditore (Administrator), who oversaw the maintenance of the accounting records relating to cash flows managed by the treasurer (Giorgi 1997). All these processes featured checks and balances aimed at preventing misreporting and accounting for transparency. As stated by Haines (2008, 154), 
the institution was able to guarantee a measure of juridical impartiality through its ability to forge decisions out of plurality and endow them with binding, civic force.

It is also relevant in terms of accountability that all positions were rotating and had a short duration of four or six months according to a model widely used in the government apparatus. The positions of the Operai were interspersed with two new entrants every two months to ensure continuity between the successive management. The offices were distributed proportionally among the four 'convents', or the urban areas belonging to the Wool Guild representatives. A four-year 'ban' between one office and another prevented the association of offices with a person, family, or shop (Haines 1989). The Operai served free of charge, whereas the Camarlingo and the notary were paid monthly salaries of eight and six lire, respectively (Haines and Riccetti 1991). Moreover, after a revision of the statute in 1338 , the Operai began to be drawn by lots rather than elected.

The number and duration of offices, their eligibility criteria, and the method of selection by lot from the pool of candidates with approved qualifications would be adjusted repeatedly throughout the history of the institution, but the guiding principle remained that the Opera should represent the entire Guild (Haines 1989). Specifically, during the dome construction, the office of the Operai maintained elements of a participatory nature that were typical of the major republican offices in the republican age: collegiality, short duration, and gratuity (Fabbri 2001).

Furthermore, in addition to traditional and permanent offices, the Guild could create new magistrates to closely monitor projects of particular importance, flanking them alongside the existing structure of the Opera, as was true for the four Provveditori della Cupola (Officers of the dome), specially elected (and not drawn) from the ranks of the Guild starting from 1419 to solicit and monitor the good conduct of the dome enterprise. Figure 4 shows two accounting entries, cross-checked using two different books, concerning the salary allowance of Filippo Brunelleschi as supervisor of the dome:

to Filippo Brunelleschi, elected Supervisor of the main dome of said church, for his provision of the said four months begun and finished as mentioned above, gold florins $12^{\prime} .5$ (Book of Resolutions, AOSMF II 178 c. 71 d)

Although their initiatives were subject to approval by the Guild consuls and the Operai, their mandate was short (six months); however, it could be extended for longer periods. The first four officials of the dome fulfilled all expectations, and their tasks were reconfirmed seven times (over three and a half years) with the justification that they were the only ones who could ensure that the dome would be safely constructed on time. It appeared that a general policy existed that could be waived in special cases of higher necessity, such as the construction of the dome. This system of transparency, weights and counterweights, cross-checks between accounting books (see Figures 4 and 5) and charges that rotated rapidly to avoid the emergence of unbalanced power centres was by no means a foregone conclusion.

Studying the abovementioned sources in light of our theoretical framework enables us to understand how all these accounting and managerial processes can be configured as a set of technologies of government. In particular, the Opera needed to define a collection of different government technologies for creating its authority and credibility, for improving its co-ordination with the other actors involved, and for efficiently dividing competencies and practical rationalities among different organs of government (Rose 1991; Dean 1996; 


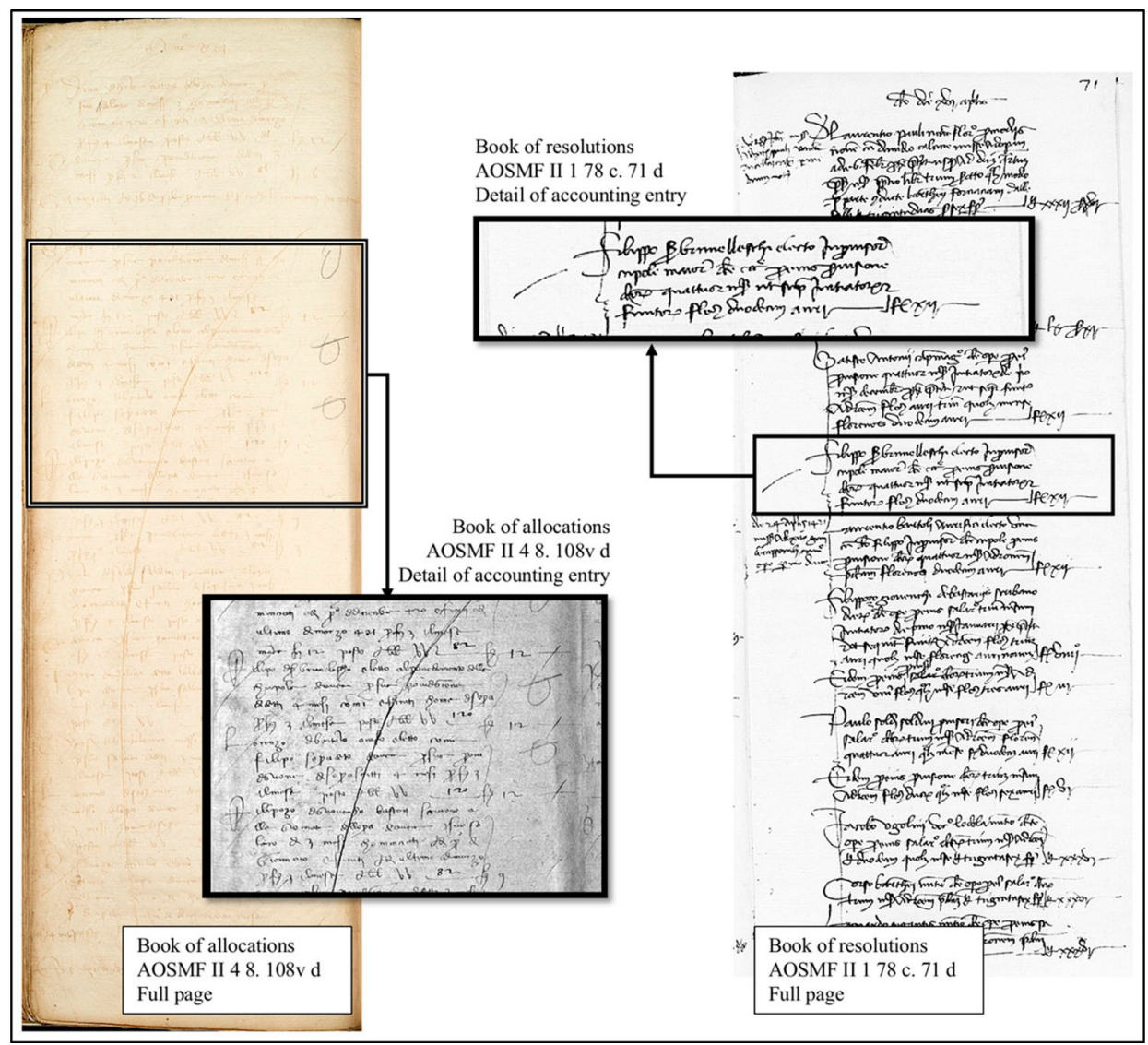

Figure 4. Accounting entries in two different books concerning the salary allowance of Filippo Brunelleschi as supervisor of the cupola.

Source: Book of allocations - AOSMF II 4 8. 108v d and Book of resolutions - AOSMF II $178 \mathrm{c} .71 \mathrm{~d}$.

Carmona, Ezzamel, and Gutiérrez 2002). However, in the period of our analysis concerning the dome construction, a dense interpenetration of skills existed between the Arte della Lana and the Opera in some of the most delicate aspects of managing a large civic enterprise under the eyes of all citizens. What is specified in this section suggests how the relationship between the Opera and the mother institution, the Wool Guild, was marked (at least during the period of the flourishing republican institutions) by a precise sense of correctness, decorum, and public responsibility. At the same time, it provides us with a valuable interpretation of the relationship among public commissioning, accounting and accountability systems, and artistic programmes in republican Florence (Haines and Riccetti 1991).

\section{Engagement of citizens and consensus building}

Florentines gave considerable attention to the activity of the Opera and its officers. The magnificent project of constructing the Cathedral and its dome and its financing with public funds led, on the one hand, to the pursuit of transparency and accountability and, on the other hand, to the willingness to manage public opinion and its consent. In fact, to be 


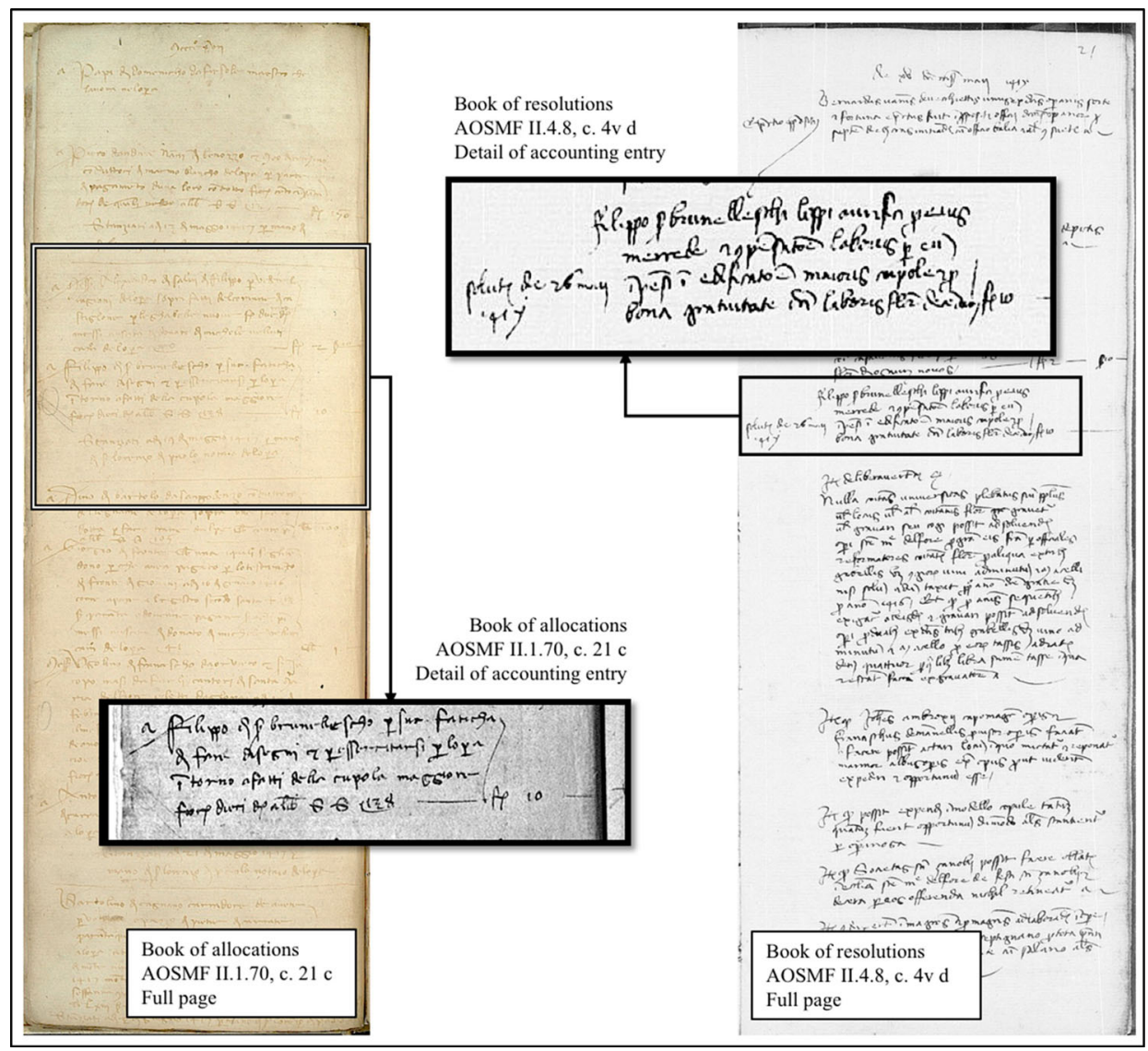

Figure 5. Accounting entries in two different books concerning Brunelleschi's first consultation with the Opera personnel before the start of the dome construction.

Source: Book of allocations - AOSMF II.1.70, c. 21 c and Book of resolutions - AOSMF II.4.8, c. 4v d d.

able to demand new and continuous funding efforts from the city government, it was necessary to demonstrate implementation of the public will. The Opera committed to this necessity through a wise process of gathering consensus for the new project (Haines 1989, 2002). The management of social partners, in a consensus-building perspective, represented a technology of government (Dean 1996) carried out by the Opera during the years of the dome construction. This technology of government aimed at improving and optimising governmentality in the Republic of Florence. The public would ensure the continuity and realisation of the enterprise. Consequently, in the face of decisions of vast responsibility, the Opera developed a tradition of consultation and consensus building that explicitly evoked the perception of its relationship with the city's government and ultimately with the Florentine populace (Haines 1989). Governmentality of the weak had to address issues associated with public financing and, consequently, the need to be accountable, transparent and, at least in principle, open to participation.

It is possible to select three moments in the history of the dome construction that signal the attention devoted by the Opera to participatory processes capable of building consensus and legitimacy: (1) the contest for the cupola project and the choice of responsibilities 
of Brunelleschi and Ghiberti at the start of construction; (2) the review of final details; and (3) the consultations inherent to building the roof lantern in the year of the dome completion.

The first moment concerns the contest for the best project of the dome in 1418, when the Operai, judges and local population were facing, among others, two beautiful projects from two talented artists, Brunelleschi and Ghiberti. They tried to reach a compromise with the joint conferral of this costly and prestigious commission but were thwarted in their aim by the intransigence of a hot-headed young Filippo (Haines 1989). The principle was that the work must be beautiful but also had to receive the approval of a set of consultative processes intended to guarantee fairness and seek consensus in the public interest. The tale of the cupola written by Manetti (1976) opens with a reference to the honorarium of ten florins paid to Brunelleschi for a first, intensive round of consultations with the Opera personnel. Figure 5 shows two accounting entries for this same payment - one in Vulgar Italian in a Book of allocations (AOSMF II.1.70, c. 21 c) and one in Latin in a Book of resolutions (AOSMF II.4.8, c. $4 \mathrm{v}$ d).

A second moment pertains to the general review of plans for completing the vault's upper reaches between 1425 and 1426, from which we can isolate another example of some of the populace-engagement procedures that the Opera used. Consensus seeking and plurality in supervision and responsibility appeared to be long-established traditions in the Opera (Haines 1989), and the inclusion of Ghiberti as a second supervisor of the cupola must be interpreted from this perspective. As reported by Haines $(1989,117)$, the procedures involved

a new round of extensive consultation with citizens and experts over a series of models and designs. Clearly, the Guild and the Opera felt the need of outside support in the last, breathtaking leap, and once again they drummed up a consensus for a new, detailed program for the remaining parts of the dome, commissioned from Brunelleschi, Ghiberti, Battista d'Antonio and one of the four Cupola officials. The decision to proceed according to these specifications was taken jointly by the consuls, Operai, and cupola officials, who technically assumed responsibility for the text their appointees had submitted.

Although Brunelleschi was de facto in charge, he was legally bound to execute a programme that was continuously refined by the traditional consultative process of the Opera: 'Even his own corrections to his calculations for the diameter of the cupola's oculus had to be approved by the prescribed bureaucratic procedures' (Haines 1989).

A third moment of consensus building relates to the roof lantern. In fact, the Operai proceeded through a remarkable series of new consultations before the last day of 1436, when they finally approved Brunelleschi's model, stating their wish to begin the lantern desired by the entire Florentine populace and invoking the powers conceded to them by the councils, people, and Commune of Florence and by the Wool Guild (Haines 1989). As reported by Haines $(1989,121)$,

[F]irst there had been a great council of theologians, learned men, architects, goldsmiths, other artisans, and Florentine citizens. Then three rounds of voting by separate commissions, each comprising two architects, two painters, two goldsmiths, one mathematician, and two capable citizens, had handed down opinions in writing. Finally, a committee of eight prominent citizens, including Cosimo de' Medici, drafted the report that was sanctioned by the final act of the Operai. The lantern should be constructed according to Filippo's model - described as the strongest, 
lightest, best lit, and most water resistant - and under his personal supervision. But the Operai should convoke and exhort him to put aside 'omnes rancores' and to consent to incorporate into his work any improvements, however small, to be derived from his competitors' entries. Once again, the architect's design had become a universal project.

\section{Responsibility toward workers of the cupola}

The construction of the Cathedral, particularly the dome, was a work-intensive task. For the 31 semesters from the beginning of the cupola effort in the summer of 1420 to its completion in the summer of 1436 , for each season, 43-85 qualified workmen are recorded, with an average presence of 65 (Haines 2012b; Terenzi 2015).

Records exist of actions taken to ensure a minimum level of social security for these workmen. The first example is that the Opera was required to pay employees compensation in cases of injury at work and to bear funeral expenses in the case of a fatal accident. Four fatal injuries at work occurred in the years between 1417 and 1436; only one occurred during the actual construction of the dome - in February 1422, Nencio di Chello fell from the walls of the dome ('chadde a terra delle mure della cupola') - whereas the other three are recorded before August 1420. This construction site represented a considerable engineering challenge and injuries were not uncommon. The most frequent cause of fatal injury was not the fall of workers from high ground but the fall of construction material on them, as described in the documentation concerning the three cases (Haines 2012a).

Table A3 of the Appendix summarises these events, the compensation accounted for by the Opera, and the archival reference to the register that contains the accounting entries. Figure 6 shows the accounting entry concerning the fatal accident for Nencio di Chello that occurred and the Opera's payment of the sum of ' 7 lire e 8 soldi' to an apothecary for his funeral. This kind of social responsibility toward the workers recorded in those years within the Opera and, in particular, during the years of the dome construction, was not customary in the construction of other cathedrals. For example, in the case of the Cathedral of Orvieto, records of assistance to sick workers are very rare, while donations were frequent during periods of illness (Riccetti 2001; Haines 2012a).

Other measures of attention and responsibility toward workers and their safety at work included: attempts to minimise the transit of workers from high to low places and vice versa; efforts to account for higher risk through higher pay; a certain limitation on the use of wine in some periods; and the severe punishment of drunkenness at work, although water at the time was considered unhealthy in the cities (Saalman 1980). However, all these elements of attention to worker safety, which clearly emerge from our sources, can also be read through our theoretical framework as 'practical rationalities' intended as mechanisms through which the authorities tried to shape, normalise and conform to their expectations the behaviours and actions of workers to achieve their aims (Servalli 2013). For example, the attempts to minimise the transit of workers from high to low places and vice versa or the limitations on the use of wine were also part of a regimen designed to ensure maximum productivity, as the time lost by descending from the walls during work hours and drunkenness at work were apparently major issues. Responsibilities toward workers and the use of government technologies (Lemke 2001) were intertwined in a system of norms and rules intended to encourage safety, on the one hand, and productivity, on the other. 


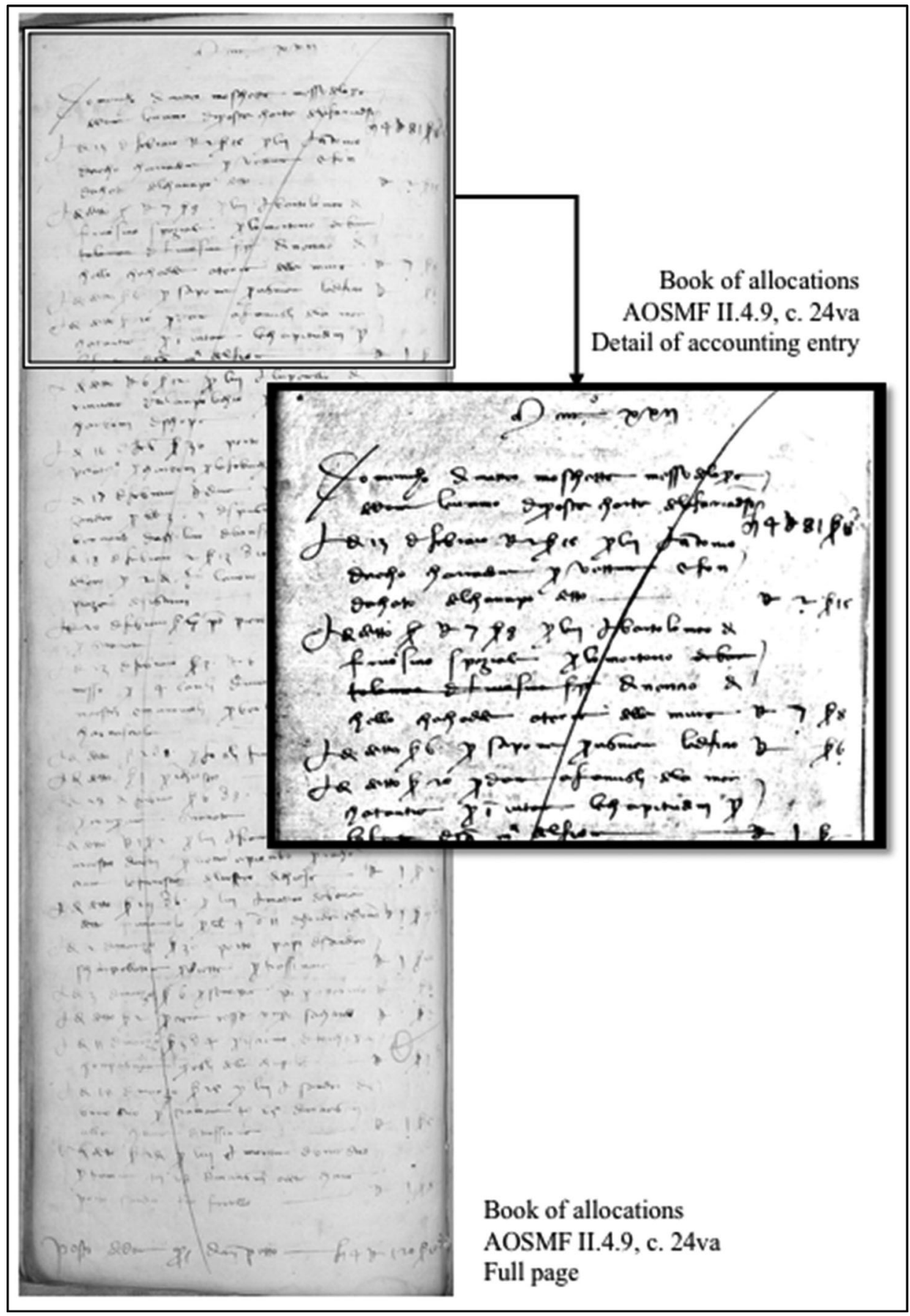

Figure 6. Accounting entry concerning the funeral of Nencio di Chello, stonecutter. Source: Book of allocations - AOSMF II.4.9, c. 24va. 
Nonetheless, the compact composition of the group and the relative stability and confidence that the workers enjoyed in the workplace (Haines 2012b) also contributed to the relatively low number of fatalities during the year of the dome construction. Unlike other great building sites, driven by teams mainly composed of occasional workers, Santa Maria del Fiore was managed traditionally with a paternalistic nature. According to Haines (2012b), this approach to constructing the dome made sense in a context of

limited but constant public funding, of experimentation with absolutely new and audacious construction methods, of self-supporting masonry that needed time to consolidate in every phase, of a workforce for the most part local and coherent, [and] of a client who felt [he was the] interpreter of the citizen will and responsible for the right management of the administration and the building site in front of the Florentine people and to God. Thus, the ethics of the Opera could marry with the architect's genius to succeed in realizing one of the most courageous structures in the history of architecture with human cost content.

\section{Discussion and conclusions}

The Opera of Santa Maria del Fiore is a remarkable institution that has long been the object of scholarly interest; in particular, Brunelleschi's dome shares with other extraordinary architectural monuments a tendency to generate myths about its realisation. (Haines 2012a). Our main objective in this study is to answer an exploratory research question on whether and how accountability systems, conceived as signs of government technologies and bureaucracy, were actually adopted by a quasi-public institution - the Opera del Duomo in Florence - during the period of the Florentine Cathedral dome construction (1420-1436). Our analysis sheds light on a complex 'medieval accountability system', based on the presence of checks and balances, the management of citizens and local partners, and consensus-building mechanisms.

In light of the theoretical framework and the study of primary and secondary sources, we have collected elements that enable us to understand what forms of accountability, bureaucracy, and government technologies were actually adopted by the Opera and the Wool Guild during the period that coincides with the last decades of the oligarchic regime of the Albizi family and the beginning of the Medicean faction ascendancy (Haines 2008). The collected evidence allows us to identify the application of 'technologies of government' hundreds of years before Foucault's arguments about governmentality. We structure our concluding discussion around three theoretical concepts - governmentality, bureaucracy and accountability - which provided us with analytical lenses through which to study our primary and secondary sources.

First, we underscore the role of bureaucracy and governmentality. As examined, the civic enterprise of the construction of the Cathedral and its dome was primarily financed by public funds. This public funding introduced a layer of complexity in the management of the enterprise, as the main actors involved needed to be accountable to both the Republic and its citizens with reference to the use of these resources. In reference to an era in which it is often difficult to apply the modern concepts of public and private, albeit intertwined and nebulous, what is essential, in the analysis of the institutional form and the Opera governance practices, is the idea of the collective good for the community as a whole. The latter distinguished the building of the Cathedral since its first rise, binding it inextricably to the city (Fabbri 2001). This binding required the Opera to legitimise 
itself in the eyes of the Republic and its citizens through efforts to achieve transparency and bureaucratisation. Foucault's observation of the rise of the state apparatus is grounded in the concepts of the legitimation process, but it is much more explicit (Foucault 1984a, 1984b; O'Neill 1986; Foucault 2010), emphasising the power of the state and the economy in politics (O'Neill 1972, 1985). Foucault sought to expand the notion of governmentality beyond the idea of state or government action: government, intended as the regulation of bodies and ways of thinking, can occur in diverse contexts - schools, churches, hospitals, factories and so forth. Here, the focus is on a quasi-public administration that uses public funds. Our sources provide intriguing elements to interpret the Opera from the perspective of a quasi-public apparatus funded by collective resources with all the consequent implications in terms of bureaucracy, transparency, governance, consensus seeking and the need for accountability.

Second, our analysis of primary and secondary sources invites us to discuss the links between the city, the Wool Guild, and the Opera in terms of technology of government. By using our theoretical framework as a lens to interpret the history that emerges from the selected sources, we are now able to understand how the Wool Guild served as the necessary link between a set of technologies of government and other kinds of technologies, such as production and communication, carried out by the Opera. The Opera was, in fact, not only an institution managing a construction site but also most prominently a generator of authority, control and regulation (Dean 1996). Moreover, the Opera needed to define a collection of different government technologies to create its authority and credibility, to improve its co-ordination with the other actors involved, and to efficiently divide competencies and practical rationalities among different organs (Rose 1991; Carmona, Ezzamel, and Gutiérrez 2002). This perspective has led us to interpret the governance, management, and accounting processes put in place during the year of the dome construction as practical rationalities (Dean 1996). Accounting is implicated in power relations and has the ability not only to represent but also to constitute various organisational phenomena (Carmona, Ezzamel, and Gutiérrez 2002). The assumption by the large mercantile Guilds of the administrative responsibility of institutions of great social importance - on the religious, symbolic, and material levels - finds its first explanation in the managerial experience of the members of those organisations (Fabbri 2001) that were able to generate such a typology of technology of government. This form of rationalised governance, also aimed at the achievement of higher managerial and financial efficiency, resonates with Weber's ideas about the implementation of rational ways of thinking into modern governments. However, we must also account for other factors, such as the political, institutional, and religious context. Our empirical evidence points to an intermingling of practices concerned with efficient ways of constructing an innovative Cathedral, reflecting and strengthening Florentine values, conducting political and civic affairs, and reflecting and strengthening religious beliefs. From this perspective, accounting is deeply involved as a vector of financial accountability that embodies economic, political, cultural, and religious matters. Moreover, if we refer to the forces and capabilities of subjects, groups, and populations that can improve and optimise governmentality (Dean 1996), we find relevant implications for the management of citizens and local partners and the search for public consensus carried out by the Opera in the years of the dome construction. The Opera and the Wool Guild were aware that it was the public will that ensured the continuity and realisation of the enterprise and were thus committed to gathering and 
growing the consensus regarding the construction of the Cathedral and the dome (Haines $1989,2002)$. All of these technologies of government represent a political rationality that involves diverse procedures and institutions (Lemke 2001) and offer novel insights for interpreting the system of powers and relations established to ensure that public funding was used to complete the Cathedral and cupola construction.

Third, we cannot study this system of relations and the related accountability model without considering the role of religious values and beliefs. Although the construction of the Cathedral represented a civic enterprise in the sense that funding was public and the Cathedral would symbolise the magnificence of an entire city, it remained the realisation of a religious temple. If we take into the account the religious context in which the Opera was operating, we cannot reduce the roles of bureaucracy, technologies of government, accounting practices and accountability processes to a set of financial control mechanisms (Quattrone 2004; Servalli 2013). In contrast, accounting and accountability practices also emerged as a response to a call for transparency and virtuousness inspired by religious values. The interpretation of our sources suggests that the specific nature of the religious belief systems surrounding the construction could represent one of the explanatory factors in the definition of the bureaucratic systems put in place by the Opera. The role played by religious entities and quasi-public institutions in this historical context highlights the need for further historical investigation in this field to better understand the characteristics of partnership with local authorities (Manetti, Bellucci, and Bagnoli 2017). However, it must be considered how these principles of ethics and good governance, coherent with a religious belief system but also consistent with the secular republican system, reflected the administrative processes of the entire Florentine municipality. A blurred boundary often existed between adherence to religious values and the search for productivity. Therefore, accountability practices should be carefully investigated in both the context of quasi-public administrations and local public authorities to highlight their role as a technology of government (Manetti, Bellucci, and Bagnoli 2017).

Finally, and most notably, our research contributes to the accounting history literature on religious institutions by highlighting many elements of answerability and accountability (Ebrahim 2003a, 2003b). If answerability is the obligation to answer enquiries regarding decisions, activities, and actions (Brinkerhoff 2004), the Opera tried to respond to this obligation by defining an accounting system inside the framework of transparent governance. It is also developed a marked attitude toward the management of citizens and local partners and consensus building. Both the Opera and the Wool Guild were aware of their responsibility to the entire city for the building of the Cathedral and for the necessity of guaranteeing disclosure and efficiency in managing public funds (Haines 1989). According to this perspective, the Opera developed a tradition of representational procedures and consensus seeking similar to the procedures and practices of the Republic of Florence. Our sources suggest that the Opera established an accountability system based on transparency, weights and counterweights, and cross-checks between accounting books and rotating charges. As a system inspired by both religious and institutional values, it was configured as a tool for a socialising form of accountability often associated with communicative actions and interactions with citizens and local partners, suggesting a downward perspective (Gambling, Jones, and Karim 1993; Ryan, Scapens, and Theobald 2002). This socialising form of accountability appears to be, in part, about keeping key partners in place and, in part, about providing a potent religious symbol for the poorer strata of 
the community, such as the construction workers who suffered injuries during the dome realisation. This tension could suggest a contradiction in the accountability system of the Opera, reflecting the type of Republic in place in Florence at the time, in which democracy appeared to mainly benefit those few people and families actually engaged in the governance of the city: those who were literate, had political and social networks, and had the means of accumulating wealth.

Our study provides an analysis of the main accountability practices adopted by the Opera during the realisation of the Cathedral's dome. The need for strong accountability (Kearns 1996; Ebrahim 2005) to the local community and other affected constituents was mainly motivated by the fact that the Opera, acting as a quasi-public administration influenced by both political and religious powers, was almost entirely financed by public funds. From this perspective, our study sheds light on how the Opera accounted for the responsibilities underlying the realisation of a monument that, six centuries later, remains a legendary landmark.

\section{Notes}

1. The accounting documents shown in Table A1 of the Appendix are available at the archive of the Opera del Duomo of Florence. They can be viewed via the project 'Gli anni della Cupola' (Fabbri 2015), an online archive that enables a search for multiple criteria and both textual and photographical visualisation of the materials accessible for the years of our study (14201436), including pre-flood photographs and the 'virtual restoration' of vanished scriptures. Although the disastrous flood of 1966 in Florence had almost completely erased the entries of many registers, a series of ultraviolet photo shoots carried out by the University of Applied Sciences of Cologne subsequently enabled improvement in the readability of many of those documents. These difficulties characterised an archive whose contents had already been reduced by the loss of many accounting books and all the models and designs that were commissioned for the dome, without considering that Brunelleschi himself often avoided giving many written indications or even detailing the invoices to avoid allowing others to understand his plans, probably for fear of plagiarism of his innovative and unprecedented work.

2. See Haines (2002) for an analytical yearly review of the consistency of the Opera's budget and the revenue of the four taxes.

3. Original transcription in Latin: 'et pro malvagia et confectis emptis pro faciendo collationem consulibus Artis Lane die 4 dicti mensis libras tres soldos otto denarios otto'.

4. Original transcription in Latin: 'Filippo lohannis exactori gabelle contractuum pro scribendo et summendo de libris dicte gabelle quamplura testamenta et seu nomina testantium in quodam quaterno (...)'.

5. Original transcription in Latin: 'Filippo ser Brunelleschi electo in provisorem cupole maioris dicte ecclesie pro eius provisione dictorum quattuor mensium ut supra initiatorum et finitorum florenos duodecim auri'.

\section{Acknowledgments}

We wish to thank the Opera of Santa Maria del Fiore for granting us access to its archives. We are particularly grateful to Lorenzo Fabbri and Giuseppe Giari for their kind and competent advice, which played a fundamental role in how we interpreted the historical documents presented in this article. We are sincerely grateful to the editor of Accounting History Review, Cheryl S. McWatters, and two anonymous referees, for their expert and insightful support in improving the manuscript towards publication.

Although the paper is the result of a team effort, Giacomo Manetti can be considered the author of the following sections: 'Introduction', 'Context of the early Florentine Renaissance', and 'Years of 
the dome construction (1420-1436)'. Marco Bellucci is the author of 'Sources and methodology', 'Accountability and governmentality in the shadow of the dome', and 'Discussion and conclusions'. Finally, Luca Bagnoli contributed to the 'Introduction', 'Sources and methodology' and the collection of primary and secondary sources.

\section{Disclosure statement}

No potential conflict of interest was reported by the authors.

\section{ORCID}

Marco Bellucci (1) http://orcid.org/0000-0002-4014-4418

\section{References}

Baker, R., and M. D. Rennie. 2017. "A Public Sector Accounting Technology and its Association with a Transition to Responsible Government." Accounting History Review 27 (2): 115-142.

Barthes, R. 1957. Mythologies. Paris: Editions du Seuil.

Bowen, G. A. 2009. "Document Analysis as a Qualitative Research Method." Qualitative Research Journal 9 (2): 27-40.

Brinkerhoff, D. W. 2004. "Accountability and Health Systems: Toward Conceptual Clarity and Policy Relevance." Health Policy and Planning 19 (6): 371-379.

Bryman, A., and E. Bell. 2015. Business Research Methods. New York: Oxford University Press.

Carmichael, A. G. 1986. Plague and the Poor in Renaissance Florence. Cambridge: Cambridge University Press.

Carmona, S., M. Ezzamel, and F. Gutiérrez. 2002. "'The Relationship Between Accounting and Spatial Practices in the Factory." Accounting, Organizations and Society 27 (3): 239-274.

Cipolla, C. M. 1976. Public Health and the Medical Profession in the Renaissance. Cambridge: Cambridge University Press.

Corbin, J., and A. Strauss. 2008. Basics of Qualitative Research: Techniques and Procedures for Developing Grounded Theory. 3rd ed. Thousand Oaks, CA: Sage.

Dean, M. 1996. "Putting the Technological Into Government." History of the Human Sciences 9 (3): 47-68.

Ebrahim, A. 2003a. "Making Sense of Accountability: Conceptual Perspectives for Northern and Southern Nonprofits." Nonprofit Management and Leadership 14 (2): 191-212.

Ebrahim, A. 2003b. "Accountability in Practice: Mechanisms for NGO's." World Development 31 (5): 813-829.

Ebrahim, A. 2005. "Accountability Myopia: Losing Sight of Organizational Learning." Nonprofit and Voluntary Sector Quarterly 34 (1): 56-87.

Fabbri, L. 2001. “L'Opera di Santa Maria del Fiore nel quindicesimo secolo: tra Repubblica fiorentina e Arte della lana." In La cattedrale e la città. Saggi sul Duomo di Firenze. Atti del VII centenario del Duomo di Firenze. Vol. 1, edited by Timothy Verdon, and Annalisa Innocenti, 319-339. Firenze: Edifir.

Fabbri, L. 2003. "La 'Gabella di Santa Maria del Fiore': il finanziamento pubblico della cattedrale di Firenze." Reti Medievali Rivista 3 (1): 1-37.

Fabbri, L. 2015. "Gli anni della Cupola: una grande risorsa per gli studi fra tradizione e innovazione." The Years of the Cupola - Studies, 1-7.

Foucault, M. 1984a. "Space, Knowledge and Power." In The Foucault Reader, edited by Paul Rabinow, 239-256. New York: Pantheon books.

Foucault, M. 1984b. "The Politics of Health in the Eighteenth Century." In The Foucault Reader, edited by Paul Rabinow, 273-290. New York: Pantheon books.

Foucault, M. 2010. The Government of Self and Others: Lectures at the Collège de France 1982-1983. New York: Palgrave Macmillan. 
Gambling, T., R. Jones, and R. Karim. 1993. "Credible Organizations: Self Regulations vs. External Standard Setting in Islamic Banks and English Charities." Financial Accountability and Management 9 (3): 195-207.

Giorgi, A. 1997. "L'Opera di Santa Maria del Fiore in età moderna." In La cattedrale e la città. Saggi sul Duomo di Firenze, edited by Timothy Verdon, and Annalisa Innocenti, 87-105. Firenze: Edifir.

Giovannoni, E., and P. Quattrone. 2018. "The Materiality of Absence: Organizing and the Case of the Incomplete Cathedral." Organization Studies 39 (7): 849-871.

Goldthwaite, R. 1968. Private Wealth in Renaissance Florence: A Study of Four Families. Princeton: Princeton University Press.

Goldthwaite, R. 1980. The Building of Renaissance Florence: An Economic and Social History. Baltimore and London: JHU Press.

Grote, A. 2009. "L'Opera del Duomo di Firenze 1285-1370: Traduzione dell'edizione originale del 1959." Studien zur Geschichte der Opera di Santa Reparata 2009: 1285-1370.

Guarini, E., F. Magli, and A. Nobolo. 2018. "Accounting for Community Building: The Municipal Amalgamation of Milan in 1873-1876." Accounting History Review 28 (1-2): 5-30.

Guasti, C. 1857. La Cupola di Santa Maria del Fiore. Barbera Bianchi: Firenze.

Guasti, C. 1887. Santa Maria del Fiore. Firenze: Tipografia di M. Ricci.

Haakonssen, K. 1995. "Republicanism." In A Companion to Contemporary Political Philosophy, edited by Robert E. Goodin, and Philip Pettit, 729-735. Cambridge: Blackwell.

Haines, M. 1989. "Brunelleschi and Bureaucracy: The Tradition of Public Patronage at the Florentine Cathedral." I Tatti Studies: Essays in the Renaissance 3: 89-125.

Haines, M. 1996. "L'arte della Lana e l'Opera del Duomo a Firenze con un accenno a Ghiberti tra due istituzioni." In Opera. Carattere e ruolo delle fabbriche cittadine fino all'inizio dell'Età Moderna, Atti della Tavola Rotonda, Villa I Tatti, Firenze, 3 aprile 1991, edited by Margaret Haines, and Lucio Riccetti, 267-294. Firenze: Olschki.

Haines, M. 2002. "La grande impresa civica di Santa Maria del Fiore." Nuova Rivista Storica 86 (1): 19-48. Haines, M. 2008. "Oligarchy and Opera: Institution and Individuals in the Administration of the Florentine Cathedral." In Florence and Beyond: Culture, Society, and Politics in Renaissance Italy; Essays in Honour of John M. Najemy, edited by David S. Peterson, and Daniel E. Bornstein, 153177. Toronto: Centre for Reformation and Renaissance Studies.

Haines, M. 2012a. "Myth And Management In The Construction Of Brunelleschi's Cupola." I Tatti Studies Essays In The Renaissance XIV-XV: 47-101. Firenze: Leo S. Olschki Editore.

Haines, M. 2012b. "Lavorare sulla cupola: sicurezza e coraggio al tempo di Brunelleschi." In E l'informe infine si fa forma ... Studi intorno a Santa Maria del Fiore in ricordo di Patrizio Osticresi, edited by Lorenzo Fabbri, and Annamaria Giusti, 181-189. Mandragora: Firenze.

Haines, M., and L. Riccetti. 1991. Opera. Carattere e ruolo delle fabbriche cittadine fino all'inizio dell'età moderna. Atti della tavola rotonda. Harvard University Centre for Italian Renaissance Studies: Harvard.

Henderson, J. 1994. Piety and Charity in Late Medieval Florence. Oxford: Oxford University Press.

Holloway, J., G. Francis, and M. Hinton. 1999. "A Vehicle for Change? A Case Study of Performance Improvement in the new Public Sector." The International Journal of Public Sector Management 12 (4): 350-364.

Hyett, F. A. 1903. Florence: her History and art to the Fall of the Republic. London: Methuen.

Hyman, Isabelle, ed. 1974. Brunelleschi in Perspective. Englewood Cliffs, NJ: Prentice-Hall.

Jacobs, K., and S. P. Walker. 2004. "Accounting and Accountability in the Iona Community." Accounting, Auditing \& Accountability Journal 17 (3): 361-381.

Jurdjevic, M. 1999. "Civic Humanism and the Rise of the Medici." Renaissance Quarterly 52 (4): 994-1020.

Kearns, K. P. 1996. Managing for Accountability: Preserving the Public Trust in Nonprofit Organizations. San Francisco: Jossey-Bass.

Kent, D. 1978. The Rise of the Medici: Faction in Florence 1426-1434. Oxford: Oxford University Press. Kent, D. 2000. Cosimo de' Medici and the Florentine Renaissance: The Patron's Oeuvre. New Haven and London: Yale University Press.

King, R. 2000. Brunelleschi's Dome: The Story of the Great Cathedral in Florence. London: Walker \& Co. Krautheimer, R. 1982. Lorenzo Ghiberti. Princeton: Princeton University Press. 
Lemke, T. 2001. "The Birth of bio-Politics: Michel Foucault's Lecture at the Collège de France on neoLiberal Governmentality." Economy and Society 30 (2): 190-207.

Manetti, A. 1976. Vita di Filippo Brunelleschi preceduta da La Novella del Grasso. Edizioni De RobertisTanturli: Milano.

Manetti, G., M. Bellucci, and L. Bagnoli. 2017. "The Management of the Plague in Florence at the Beginning of the Renaissance: The Role of the Partnership Between the Republic and the Confraternita of Misericordia." Accounting History 22 (4): 510-529.

Miller, P., and N. Rose. 1990. "Governing Economic Life." Economy and Society 19 (1): 1-31.

Munslow, A. 2007. Narrative and History. Basingstoke: Palgrave Macmillan.

Najemy, J. M. 2008. A History of Florence, 1200-1575. Hoboken: John Wiley \& Sons.

O'Neill, J. 1972. "On Body Politics." In Recent Sociology No. 4, Family, Marriage and the Struggle of the Sexes, edited by Hans Peter Dreitzel, 251-267. New York: Collier-Macmillan.

O'Neill, J. 1985. Five Bodies: The Human Shape of Modern Society. Ithaca: Cornell University Press.

O'Neill, J. 1986. "The Disciplinary Society: From Weber to Foucault." The British Journal of Sociology 37 (1): 42-60.

Padgett, J. F., and C. K. Ansell. 1993. "Robust Action and the Rise of the Medici, 1400-1434." American Journal of Sociology 98 (6): 1259-1319.

Peterson, D. S., and D. E. Bornstein. 2008. "Introduction." In Florence and Beyond: Culture, Society and Politics in Renaissance Italy; Essays in Honour of John M. Najemy, edited by David S. Peterson, and Daniel E. Bornstein, 1-6. Toronto: Toronto: Centre for Reformation and Renaissance Studies.

Quattrone, P. 2004. "'A Accounting for God. Accounting and Accountability Practices in the Society of Jesus (Italy, 16th-17th Centuries)." Accounting, Organizations and Society 29 (7): 647-683.

Rapley, T. 2007. Doing Conversation, Discourse and Document Analysis. London: Sage.

Riccetti, L. 2001. "Pranzi di cantiere." In Scrivere il Medioevo. Lo spazio, la santità, il cibo. Un libro dedicato ad Odile Redon, edited by Bruno Laurioux, and Laurence Moulinier-Brogi, 351-367. Roma: Viella.

Roberts, J. 1991. "The Possibilities of Accountability." Accounting, Organizations and Society 16: 355-368.

Roberts, J. 1996. "From Discipline to Dialogue: Individualizing and Socialising Forms of Accountability." In Accountability: Power Ethos and the Technologies of Managing, edited by Rolland Munro, and Jan Mouritsen, 40-61. London: International Thompson Business Press.

Rose, N. 1991. "Governing by Numbers: Figuring out Democracy." Accounting, Organizations and Society 16 (7): 673-692.

Rose, N., and P. Miller. 1992. "Political Power Beyond the State: Problematic of Government." The British Journal of Sociology 43 (2): 174-205.

Rubinstein, N. 1971. II Governo di Firenze Sotto I Medici (1434-1494). Firenze: La Nuova Italia.

Ryan, B., R. W. Scapens, and M. Theobald. 2002. Research Method \& Methodology in Finance \& Accounting. London: Thomsom.

Saalman, H. 1980. Filippo Brunelleschi. The Cupola of Santa Maria del Fiore. London: Zwemmer.

Sargiacomo, M. 2009. "Accounting for the "Good Administration of Justice": The Farnese State of Abruzzo in the Sixteenth Century." Accounting History 14 (3): 235-267.

Sargiacomo, M., L. lanni, A. D'Andreamatteo, and L. D'Amico. 2016. "Accounting and the Government of the Agricultural Economy: Arrigo Serpieri and the Reclamation Consortia." Accounting History Review 26 (3): 307-331.

Servalli, S. 2013. "The Interface of Power and Charity in the Government of Poor." Accounting, Auditing \& Accountability Journal 26 (8): 1306-1341.

Sgrilli, B. S. 1733. Descrizione e studi dell'insigne Fabbrica di Santa Maria del Fiore. Paperini: Firenze.

Smart, B. 1995. Michel Foucault. Critical Assessments: Rationality, Power and Subjectivity. London: Routledge.

Strathern, P. 2007. Medici: "Godfathers of the Renaissance". New York: Vintage Publishers.

Tagliaventi, I. 2009. La cattedrale gotica. Spirito e struttura della più grande opera d'arte della città occidentale. Firenze: Alinea.

Terenzi, P. 2015. "Maestranze e organizzazione del lavoro negli Anni della Cupola." The Years of the Cupola - Studies, 1-109.

Weber, M. 1922. Economy and Society: An Outline of Interpretive Sociology. Berkley: University of California Press. 


\section{Appendix}

Table A1. Primary sources.

\begin{tabular}{|c|c|c|c|c|}
\hline Name & $\begin{array}{l}\text { Number and } \\
\text { typology }\end{array}$ & Archive & $\begin{array}{l}\text { Archival unit code (years of } \\
\text { reference) }\end{array}$ & $\begin{array}{l}\text { Main contents used for the } \\
\text { present study }\end{array}$ \\
\hline $\begin{array}{l}\text { Register of contracts } \\
\text { (Registro di } \\
\text { allogagioni) }\end{array}$ & 1 register & $\begin{array}{l}\text { Archivio } \\
\text { dell'Opera di } \\
\text { Santa Maria } \\
\text { del Fiore }\end{array}$ & I 14 (1431-1503) & $\begin{array}{l}\text { Accounting entries for } \\
\text { assignments and cash } \\
\text { accounting }\end{array}$ \\
\hline $\begin{array}{l}\text { Register of } \\
\text { resolutions (Registro } \\
\text { di deliberazioni) }\end{array}$ & 1 register & $\begin{array}{l}\text { Archivio } \\
\text { dell'Opera di } \\
\text { Santa Maria } \\
\text { del Fiore }\end{array}$ & II 21 (1425-1436) & $\begin{array}{l}\text { Accounting entries for } \\
\text { decisions and expenses } \\
\text { from the Operai }\end{array}$ \\
\hline $\begin{array}{l}\text { Book of resolutions } \\
\text { (Bastardelli di } \\
\text { deliberazioni) }\end{array}$ & 19 registers & $\begin{array}{l}\text { Archivio } \\
\text { dell'Opera di } \\
\text { Santa Maria } \\
\text { del Fiore }\end{array}$ & 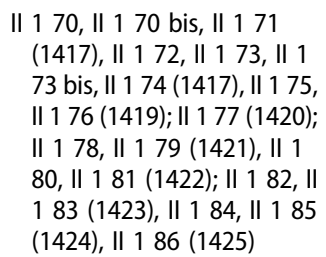 & $\begin{array}{l}\text { Accounting entries for } \\
\text { decisions and expenses } \\
\text { from the Operai }\end{array}$ \\
\hline $\begin{array}{l}\text { Books of allocations } \\
\text { (Bastardelli di } \\
\text { stanziamenti) }\end{array}$ & 4 registers & $\begin{array}{l}\text { Archivio } \\
\text { dell'Opera di } \\
\text { Santa Maria } \\
\text { del Fiore }\end{array}$ & $\begin{array}{l}\text { II } 48 \text { (RR) (1417-1421), II } 49 \\
\text { (SS) (1421-1425), II } 412 \\
\text { (BB) (1425-1430), II } 413 \\
\text { (CC) (1430-1436) }\end{array}$ & $\begin{array}{l}\text { Accounting entries for } \\
\text { expenses and allocations } \\
\text { from the Operai }\end{array}$ \\
\hline $\begin{array}{l}\text { Notebooks of the } \\
\text { administrator } \\
\text { (Quaderni del } \\
\text { provveditore) }\end{array}$ & 2 notebooks & $\begin{array}{l}\text { Archivio } \\
\text { dell'Opera di } \\
\text { Santa Maria } \\
\text { del Fiore }\end{array}$ & $\begin{array}{l}\text { II } 44 \text { (1432-1434/6), I| } 411 \\
\quad(1419-1426)\end{array}$ & $\begin{array}{l}\text { Accounting entries of the } \\
\text { Provveditore that put into } \\
\text { practice the decision of the } \\
\text { Operai }\end{array}$ \\
\hline $\begin{array}{l}\text { Notebook of debtors } \\
\text { (Quaderno di debitori) }\end{array}$ & 1 notebook & $\begin{array}{l}\text { Archivio } \\
\text { dell'Opera di } \\
\text { Santa Maria } \\
\text { del Fiore }\end{array}$ & II 434 (1424-1425) & $\begin{array}{l}\text { Accounting entries kept by } \\
\text { the Provveditore }\end{array}$ \\
\hline $\begin{array}{l}\text { Cash books (Quaderni } \\
\text { di cassa) }\end{array}$ & 2 registers & $\begin{array}{l}\text { Archivio } \\
\text { dell'Opera di } \\
\text { Santa Maria } \\
\text { del Fiore }\end{array}$ & VIII 11 (1434), VIII 12 (1435) & $\begin{array}{l}\text { Accounting entries kept by } \\
\text { the Camarlingo }\end{array}$ \\
\hline Wool guild statute & 1 statute & $\begin{array}{l}\text { Archivio di Stato } \\
\text { di Firenze }\end{array}$ & ADL 3 (1333) & $\begin{array}{l}\text { Section of the } 1333 \text { statute } \\
\text { of the Wool Guild } \\
\text { concerning the } \\
\text { management of the Opera } \\
\text { del Duomo }\end{array}$ \\
\hline $\begin{array}{l}\text { Wool guild registers } \\
\text { of resolutions }\end{array}$ & 3 registers & $\begin{array}{l}\text { Archivio di Stato } \\
\text { di Firenze }\end{array}$ & $\begin{array}{l}\text { ADL } 49 \text { (1408-1427), ADL } 50 \\
\quad(1427-1432), \text { ADL } 51 \\
(1432-1439)\end{array}$ & $\begin{array}{l}\text { Resolutions concerning the } \\
\text { management of the Opera } \\
\text { del Duomo }\end{array}$ \\
\hline
\end{tabular}

Table A2. Main secondary sources.

\begin{tabular}{ll}
\hline Reference & Main contents used for the present study \\
\hline $\begin{array}{c}\text { Fabbri, L. 2001. "L'Opera di Santa Maria del Fiore nel } \\
\text { quindicesimo secolo: tra Repubblica fiorentina e Arte }\end{array}$ & $\begin{array}{c}\text { Reconstruction of the role of accountability and governing } \\
\text { practices adopted by the Opera during the period of the } \\
\text { della lana." In La cattedrale e la città. Saggi sul Duomo di } \\
\text { dome's construction (1420-1436); moreover, } \\
\text { Firenze. Atti del VIl centenario del Duomo di Firenze. Vol. 1., } \\
\text { understanding of how the project of the cathedral and, in } \\
\text { edited by Timothy Verdon and Annalisa Innocenti, 319- } \\
\text { particular, of the dome fits as a public work in the early } \\
\text { 339. Firenze: Edifir. }\end{array}$ \\
$\begin{array}{ll}\text { Fabbri, L. 2003. "La 'Gabella di Santa Maria del Fiore': il } \\
\text { institutional and financial perspective. }\end{array}$ \\
finanziamento pubblico della cattedrale di Firenze." Reti \\
Medievali Rivista, 3 (1): 1-37. \\
Giorgi, A. 1997. "L'Opera di Santa Maria del Fiore in età \\
moderna." In: La cattedrale e la città. Saggi sul Duomo di \\
Firenze, edited by Timothy Verdon and Annalisa Innocenti, \\
87-105. Firenze: Edifir.
\end{tabular}


Table A2. Continued.

\begin{tabular}{l}
\hline Reference \\
\hline Grote, A. 2009. "L'Opera del Duomo di Firenze 1285-1370: \\
Traduzione dell'edizione originale del 1959." Studien zur \\
Geschichte der Opera di Santa Reparata, 2009: 1285-1370. \\
Haines, M. 1989. "Brunelleschi and Bureaucracy: The \\
Tradition of Public Patronage at the Florentine Cathedral." \\
I Tatti Studies 3 (1989): 89-125. \\
Haines, M. 2002. "La grande impresa civica di Santa Maria \\
del Fiore" Nuova Rivista Storica 86 (1): 19-48. \\
Haines, M. 2008 "Oligarchy and Opera: Institution and \\
Individuals in the Administration of the Florentine \\
Cathedral.", In Florence and Beyond: Culture, Society, and \\
Politics in Renaissance Italy; Essays in Honour of John \\
M. Najemy, edited by David S. Peterson and Daniel \\
E. Bornstein, 153-177. Toronto: Centre for Reformation \\
and Renaissance Studies. \\
Haines, M. 2012a. "Myth And Management In The \\
Construction Of Brunelleschi's Cupola." I Tatti Studies \\
Essays In The Renaissance, XIV-XV: 47-101. Firenze: Leo \\
S. Olschki Editore. \\
Haines, M. 2012b. "Lavorare sulla cupola: sicurezza e \\
coraggio al tempo di Brunelleschi." In E l'informe infine si \\
fa forma... Studi intorno a Santa Maria del Fiore in ricordo \\
di Patrizio Osticresi, edited by Lorenzo Fabbri and \\
Annamaria Giusti, 181-189. Firenze: Mandragora. \\
Haines, M. and G. Battista, 2015. "Un'altra storia. Nuove \\
prospettive sul cantiere della cupola di Santa Maria del \\
Fiore." The years of the Cupola - Studies. ISSN: 2364-6373 \\
Saalman, H. 1980. Filippo Brunelleschi. The Cupola of Santa \\
Maria del Fiore. London: Zwemmer.
\end{tabular}

Table A3. Accounting entries concerning accidents at work and consequent compensations.

\begin{tabular}{|c|c|c|c|}
\hline Object of the accounting entry & Date & Excerpt of the accounting entry & Archival reference \\
\hline \multirow[t]{2}{*}{$\begin{array}{l}\text { Expenses and decision not to } \\
\text { demand from the heirs of Lotto di } \\
\text { Guido, stonecutter, the collection } \\
\text { of a debt four days after his death }\end{array}$} & 14 May 1420 & $\begin{array}{l}\text { (...) 'mutuet et tradat Lotto Guidonis } \\
\text { magistro in hedificio dicte Opere } \\
\text { muranti et seu alii pro eo legitime } \\
\text { recipienti libras decem f.p. pro } \\
\text { expendendo in rebus sibi necessariis } \\
\text { pro eius liberatione, qui hac presente } \\
\text { die cecidit de tribunetta murando } \\
\text { super cappellis parvulis eiusdem et } \\
\text { dicitur in fine mortis permanere. }\end{array}$ & $\begin{array}{l}\text { Book of resolutions - } \\
\text { AOSMF II.1.77, c. } 39 \mathrm{vc}\end{array}$ \\
\hline & 18 May 1420 & $\begin{array}{l}\text { 'Jachopo d'Ugholino deto l'Alodola de' } \\
\text { dare lire venti soldi quatro per lui a } \\
\text { Lotto di Ghuido fu scharpelatore a } \\
\text { chui.dDio faccia pacie che chadde } \\
\text { dalla terza trebunetta, e quali denari } \\
\text { restava a.ddare e chonsiderato il } \\
\text { chaxo della sua morte gli furono } \\
\text { lasciati' }\end{array}$ & $\begin{array}{l}\text { Book of allocations - } \\
\text { AOSMF II.4.8, c. 79c }\end{array}$ \\
\hline $\begin{array}{l}\text { Funeral expenses for the death of } \\
\text { labourer Francesco D'Agnolo }\end{array}$ & 3 June 1420 & $\begin{array}{l}\text { 'Lire } 10 \text { soldi } 15 \text { ebe Bartolomeo di } \\
\text { Fruoxino speziale per più spese fate } \\
\text { per lo mortorio di Franciescho } \\
\text { d'Agnolo manovale che chadde dal } \\
\text { palcho della trebunetta' }\end{array}$ & $\begin{array}{l}\text { Book of allocations - } \\
\text { AOSMF II.4.8, c. 81va }\end{array}$ \\
\hline $\begin{array}{l}\text { Funeral expenses for the death of } \\
\text { labourer Donato di Valentino }\end{array}$ & 18 July 1420 & $\begin{array}{l}\text { 'A di detto lire } 9 \text { soldi } 15 \text { per lui a } \\
\text { Tomaxo di ser Lorenzo speziale per } \\
\text { lo mortorio di Donato di Valentino } \\
\text { che chadde de le mura' }\end{array}$ & $\begin{array}{l}\text { Book of allocations - } \\
\text { AOSMF II.4.8, c. } 88 \mathrm{a}\end{array}$ \\
\hline
\end{tabular}


Table A3. Continued.

\begin{tabular}{|c|c|c|c|}
\hline Object of the accounting entry & Date & Excerpt of the accounting entry & Archival reference \\
\hline \multirow[t]{2}{*}{$\begin{array}{l}\text { Funeral expenses for the death of } \\
\text { stonecutter Nencio di Chello, also } \\
\text { known as 'll Nencino' }\end{array}$} & $\begin{array}{l}13 \text { February } \\
1422\end{array}$ & $\begin{array}{l}\text { (...) 'pro expensis mortorii Nenci Chelli } \\
\text { scarpellatoris defuncti in dicta } \\
\text { Opera' }\end{array}$ & $\begin{array}{l}\text { Book of allocations - } \\
\text { AOSMF II.1.80, c. } 71 \mathrm{vf}\end{array}$ \\
\hline & $\begin{array}{l}13 \text { February } \\
1422\end{array}$ & $\begin{array}{l}\text { 'lire } 7 \text { soldi } 8 \text { per lui a Bartolomeo di } \\
\text { Fruosino speziale per lo mortorio di } \\
\text { Nencio di Chello che chadde a terra } \\
\text { delle mura' }\end{array}$ & $\begin{array}{l}\text { Book of allocations - } \\
\text { AOSMF II.4.9, c. } 24 \mathrm{va}\end{array}$ \\
\hline $\begin{array}{l}\text { Registration of the daily wages of an } \\
\text { ailing unskilled worker, Jacopo } \\
\text { D'Ugolino, detto l'Allodola }\end{array}$ & 29 July 1423 & $\begin{array}{l}\text { 'Item viso qualiter de presenti mense } \\
\text { iulii lacobus Ugolini l'Allodola } \\
\text { manovalis Opere admictantur sibi } \\
\text { sex dies quibus stetit domo propter } \\
\text { infirmitatem et quod Filippozus } \\
\text { Bastarii admictat et scribi possit in } \\
\text { libro dierum dictos dies sex et sic } \\
\text { solvi possit, teneatur et debeat per } \\
\text { camerarium Opere predicte' }\end{array}$ & $\begin{array}{l}\text { Book of resolutions - } \\
\text { AOSMF II.1.83, c. 3ve }\end{array}$ \\
\hline $\begin{array}{l}\text { Authorisation to accredit six work } \\
\text { days lost by master Piero del } \\
\text { Cofaccia wounded by a falling rock }\end{array}$ & $\begin{array}{l}29 \text { March } \\
1428\end{array}$ & $\begin{array}{l}\text { 'Item quod Filippozius scribanus Opere } \\
\text { possit ad librum scribere sex } \\
\text { giornatas, (...), propter } \\
\text { percussionem quam habuit de } \\
\text { quodam saxo quod cecidit super eius } \\
\text { blachio a culmine cupole magne' }\end{array}$ & $\begin{array}{l}\text { Book of resolutions - } \\
\text { AOSMF II.2.1, c. 80vc }\end{array}$ \\
\hline $\begin{array}{l}\text { Payment for compensation to master } \\
\text { - Betto di Giagio - struck by a brick }\end{array}$ & $\begin{array}{l}4 \text { November } \\
1429\end{array}$ & $\begin{array}{l}\text { 'Betto di Giagio maestro di scharpello } \\
\text { de' avere lire sei p. a.llui dati per } \\
\text { ristutizione d'una perchossa ebe } \\
\text { d'uno mattone chade di sulla } \\
\text { chupola e stette più dì che non } \\
\text { lavorò (....)' }\end{array}$ & $\begin{array}{l}\text { Book of allocations - } \\
\text { AOSMF II.4.12, c. 117(c. } \\
116 \text { ant.)a }\end{array}$ \\
\hline $\begin{array}{l}\text { Payment to compensate an unskilled } \\
\text { worker - Nencio di Matteo } \\
\text { Cotignola - wounded by the fall of } \\
\text { a rock }\end{array}$ & 31 July 1433 & $\begin{array}{l}\text { 'A Nencio di Matteo Chotingniuola } \\
\text { manovale lire quatro p., e qua' } \\
\text { denari gli operai a lui danno per dì X } \\
\text { è stato malato per uno sasso gli } \\
\text { chade in su le schiene, } a \cdot \text { libro C a } \\
\text { c. } 211^{\prime}\end{array}$ & $\begin{array}{l}\text { Book of allocations - } \\
\text { AOSMF II.4.13, c. } 60 \mathrm{v}(\mathrm{c} . \\
59 \mathrm{v} \text { ant.)a }\end{array}$ \\
\hline $\begin{array}{l}\text { Payment to master - Nanni D'Ellero - } \\
\text { for compensation for an accident }\end{array}$ & 20 July 1429 & $\begin{array}{l}\text { 'Nanni d'Ellero maestro dell'Opera de' } \\
\text { avere lire due } p \text {. a.llui chonceduti per } \\
\text { scioperio auto per male si fece } \\
\text { nell'Opera, chome apare } a \cdot \text { libro } \\
\text { segnato B a c. } 137^{\prime}\end{array}$ & $\begin{array}{l}\text { Book of allocations - } \\
\text { AOSMF II.4.12, c. } 112 \text { (c. } \\
111 \text { ant.) f, allocations }\end{array}$ \\
\hline $\begin{array}{l}\text { Account for a master - Checco di } \\
\text { Meo di Ciechino - for days worked } \\
\text { and days spent injured }\end{array}$ & $\begin{array}{l}29 \\
\text { November } \\
1435\end{array}$ & $\begin{array}{l}\text { 'E a dì } 21 \text { di novenbre lire quatordici } \\
\text { per di } 20 \text { diliberorono gli operai fosse } \\
\text { paghato di dì } 29 \text { lavoratoi, stette } \\
\text { infermo, messi a uscita di giornate a } \\
\text { c. 44' }\end{array}$ & $\begin{array}{l}\text { Cash book - AOSMF } \\
\text { VIII.1.2, c. } 7 \mathrm{v}-8 \mathrm{~b}\end{array}$ \\
\hline $\begin{array}{l}\text { Authorisation to credit half of the } \\
\text { daily wages lost by a worker - } \\
\text { Checco D'Andrea detto il Fiaschetta } \\
\text { - injured in the eye }\end{array}$ & $\begin{array}{l}31 \text { March } \\
1436\end{array}$ & $\begin{array}{l}\text { 'Diliberorno che al Frasschetta } \\
\text { Filippozzo gli metesse mezze l'opere } \\
\text { del tenpo ch'egli ha perduto pel male } \\
\text { che si fece a l'occhio ne l'Opera, non } \\
\text { pasando la somma del tutto sei } \\
\text { opere' }\end{array}$ & $\begin{array}{l}\text { Notebook of the } \\
\text { administrator - AOSMF } \\
\text { Il.4.4, c. } 37 \mathrm{vg}\end{array}$ \\
\hline $\begin{array}{l}\text { Ruling in favour of an unskilled } \\
\text { worker - Nencio di Chello - } \\
\text { wounded in the head by a stone }\end{array}$ & $\begin{array}{l}13 \text { June } \\
1421\end{array}$ & $\begin{array}{l}\text { 'Nencius Chelli magister sive manovalis } \\
\text { in dicta Opera diebus proxime } \\
\text { elapsis in ipsa Opera laborando fuit } \\
\text { a quodam lapide tunc cadente } \\
\text { vulneratus super capite et propterea } \\
\text { in domo sua infirmus permanet' }\end{array}$ & $\begin{array}{l}\text { Book of resolutions - } \\
\text { AOSMF II.1.78, c.41b }\end{array}$ \\
\hline
\end{tabular}

